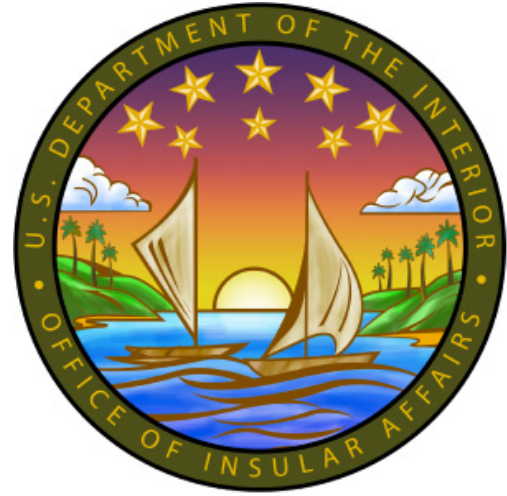

Produced under direction of the U.S. Department of the Interior Office of Insular Affairs by the National Renewable Energy Laboratory (NREL) under Interagency Agreement IAG-101773 and Task No WFF4.4000.

\section{American Samoa Initial Technical Assessment Report} Sarah Busche, Misty Conrad, Kip Funk, Alicen Kandt, Peter McNutt
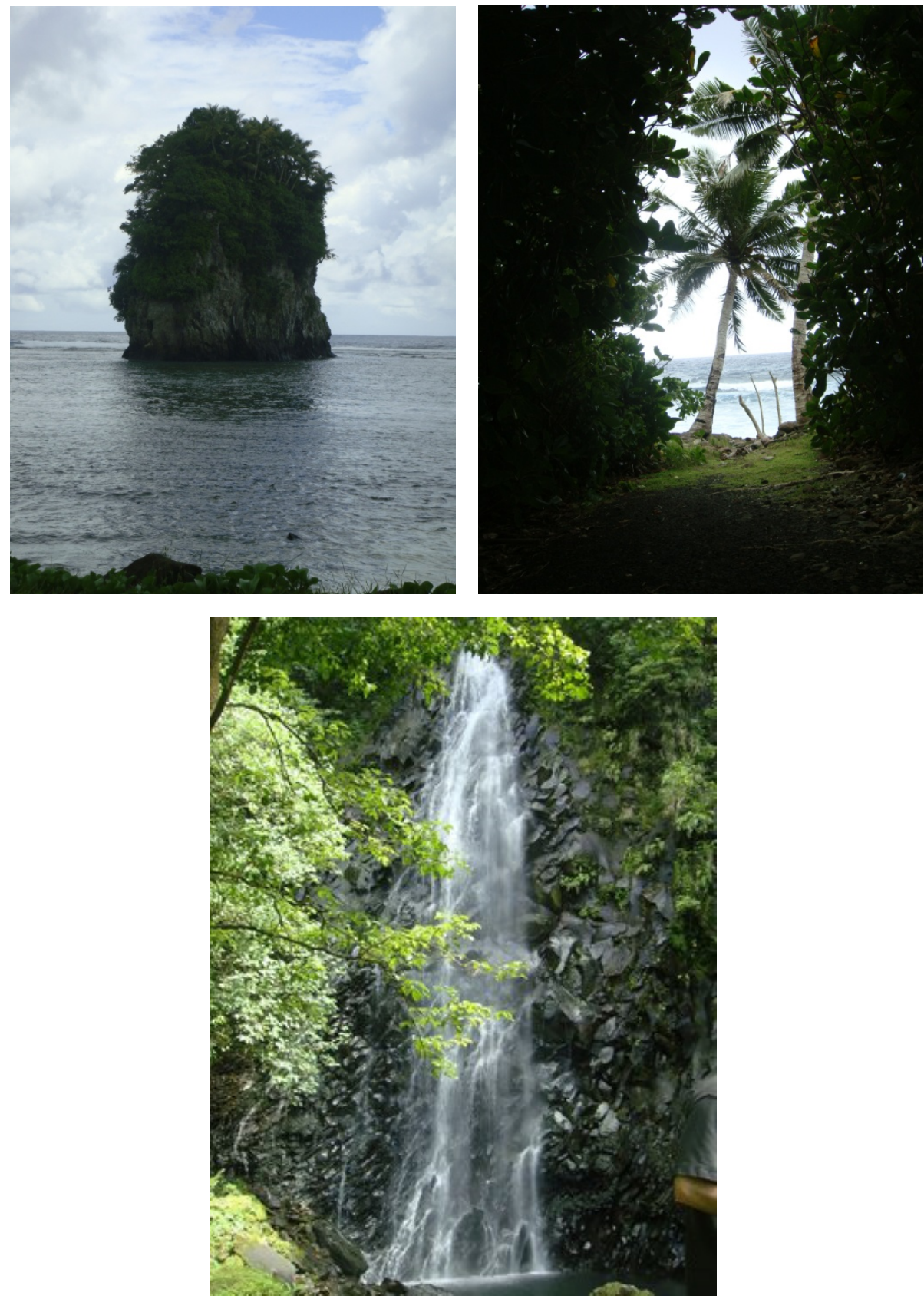


\section{American Samoa Initial Technical Assessment Report}

\section{Sarah Busche, Misty Conrad, Kip Funk, Alicen Kandt, Peter McNutt}

Disclaimer: This manuscript has been authored by employees of the Alliance for Sustainable Energy, LLC ("Alliance") under Contract No. DE-AC36-08GO28308 with the U.S. Department of Energy (“DOE”).

Neither Alliance, DOE, the United States government nor any agency thereof, nor any of their employees, makes any warranty, express or implied, or assumes any legal liability or responsibility for the accuracy, completeness, or usefulness of any information, apparatus, product, or process disclosed in this manuscript, or represents that its use would not infringe privately owned rights. Reference herein to any specific commercial product, process, or service by trade name, trademark, manufacturer, or otherwise does not necessarily constitute or imply its endorsement, recommendation, or favoring by Alliance, DOE or the United States Government or any agency thereof. The views and opinions of authors expressed herein do not necessarily state or reflect those of Alliance, DOE or the United States government or any agency thereof.

Cover photos courtesy of: NREL/PIX 19414, 19416, 19417

NREL is a national laboratory of the U.S. Department of Energy, Office of Energy Efficiency \& Renewable Energy, operated by the Alliance for Sustainable Energy, LLC. Contract No. DE-AC36-08G028308
Technical Report NREL/TP-7A40-50905

September 2011 


\section{Contacts and Team Members}

\section{Department of the Interior}

Tony Babauta

Assistant Secretary

Office of Insular Affairs

U.S. Department of Interior

Washington, DC 20240

Office Phone: (202) 208-6816

Nikolao Pula

Director

Office of Insular Affairs

U.S. Department of Interior

Washington, DC 20240

Office Phone: (202) 208-6816

E-mail: nikolao_pula@ios.doi.gov

Charlene Leizear

Director of Technical Assistance

Office of Insular Affairs

U.S. Department of Interior

Washington, DC 20240

Office Phone: (202) 208-3239

E-mail: charlene_leizear@ios.doi.gov

Angie Williams

U.S. Department of the Interior

Office of Insular Affairs

Washington, DC 20240

Office Phone: (202) 208-3003

E-mail: angela_williams@ios.doi.gov

Lydia Faleofine-Nomura

U.S. Department of the Interior

American Samoa Field Office

doioia@blueskynet.as

\section{National Renewable Energy Laboratory}

Misty Dawn Conrad

Senior Technical Project Leader

Office Phone: (303) 384-7467

E-mail: misty.conrad@nrel.gov

Sarah Busche

Energy Analyst III

Office Phone: (303) 275-4383

E-mail: sarah.busche@nrel.gov

Kip Funk

Engineer

Office Phone: (303) 275-3213

E-mail: kip.funk@nrel.gov

Scott Haase

Senior Engineer

Office Phone: (303) 275-3057

E-mail: scott.haase@nrel.gov

Peter McNutt

Senior Engineer

Office Phone: (303) 384-6767

E-mail: peter.mcnutt@nrel.gov

Alicen Kandt

Senior Engineer

Office Phone: (303) 384-7518

E-mail: alicen.kandt@nrel.gov 


\section{Acknowledgments}

The National Renewable Energy Laboratory (NREL) thanks the U.S. Department of the Interior's Office of Insular Affairs for its interest in securing NREL's technical expertise. In particular, NREL and the entire assessment team are grateful to the facility managers, directors, engineers, and operators for their generous assistance and cooperation during site visits and countless teleconferences with American Samoa.

Office of the Governor: Toetasi Tuiteleapaga

American Samoa Community College: Dr. Seth Galeai, ASCC President; Kenape Aumavae, and Sal Poloai

American Samoa Power Authority: Chief Executive Officer Andra Samoa, Reno Vivao, Ted Le'iato, Joachim Fong, and Siva Kumar

American Samoa Environmental Protection Agency: Fanuatele Dr. To'afa Vaiaga'e, Faamao Asalele, Phil Wiles, and Tim Bodell

U.S. Environmental Protection Agency Region 9: Carl Goldstein and Michael Wolfram

Territorial Energy Office: Mauigoa Reupena Tagaloa, Fala Leasiolagi and John Kirby

Department of Agriculture Natural Resources Conservation Service: Brian Peck

National Park Service: Mike Reynolds

Chamber of Commerce: Joey Cummings

American Samoa Historic Preservation Office: David Herdich

Island Energy \& Marine: Jeff Shively

National Renewable Energy Laboratory: Matthew Hartle, Dan Olis, and Charles Newcomb 


\section{Abstract}

On March 1, 2010, Assistant Secretary of the Interior Tony Babauta invited governors and their staff from the Interior Insular Areas to meet with senior principals at the National Renewable Energy Laboratory (NREL). Meeting discussions focused on ways to improve energy efficiency and increase the deployment of renewable energy technologies in the U.S. Pacific Territories. In attendance were Governors Felix Camacho (Guam), Benigno Fitial (Commonwealth of the Northern Mariana Islands), and Togiola Tulafono, (American Samoa). This meeting brought together major stakeholders to learn and understand the importance of developing a comprehensive strategic plan for implementing energy efficiency measures and renewable energy technologies.

For several decades, dependence on fossil fuels and the burden of high oil prices have been a major concern but never more at the forefront as today. With unstable oil prices, the volatility of fuel supply and the economic instability in American Samoa, energy issues are a high priority. In short, energy security is critical to American Samoa's future economic development and sustainability.

Under an interagency agreement, funded by the Department of Interior's Office of Insular Affairs, NREL was tasked to deliver technical assistance to the islands of American Samoa. Technical assistance included conducting an initial technical assessment to define energy consumption and production data, establish an energy consumption baseline, and assist with the development of a strategic plan. The assessment and strategic plan will be used to assist with the transition to a cleaner energy economy.

NREL provided an interdisciplinary team to cover each relevant technical area for the initial energy assessments. Experts in the following disciplines traveled to American Samoa for on-island site assessments:

- Energy Efficiency and Building Technologies

- Integrated Wind-Diesel Generation

- Transmission and Distribution

- Solar Technologies

- Biomass and Waste-to-Energy.

In addition to these core disciplines, team capabilities also included expertise in program analysis, project financing, energy policy and energy planning.

The intent of the technical assessment was to provide American Samoa with a baseline energy assessment. From the baseline, various scenarios and approaches for deploying cost effective energy efficiency and renewable energy technologies could be created to meet American Samoa's objectives. The information provided in this energy assessment will be used as input in the development of a draft strategic plan and the development of scenarios and strategies for deploying cost-effective energy efficiency and renewable products. 


\section{Executive Summary}

This report provides findings of an initial energy assessment for American Samoa; the first of several steps in developing a comprehensive energy strategy. This document is one deliverable in the scope of work for American Samoa that includes three main objectives:

1. Establish an energy task force to address energy issues, identify barriers and opportunities, and establish priorities.

2. Gather available data and publish an initial island assessment report to establish an energy baseline and identify energy efficiency and renewable energy opportunities.

3. Develop a draft energy strategic plan that will provide American Samoa various scenarios and approaches of cost-effective energy efficiency and renewable energy technologies that will meet American Samoa's objectives.

This report meets the second objective of establishing a baseline and identifying opportunities to reduce energy costs and fossil fuel dependence. A baseline is created by collecting various data points to establish a reference against which future progress can be measured. The baseline facilitates comparison across sectors through trend identification and provides a tool for goal setting and measuring success of those goals.

The information compiled in this assessment will be used as input in the development of a draft strategic plan to meet the third project objective. This report provides a summary of the data collected pertaining to energy production, consumption, and efficiencies. The report discusses energy efficiency and renewable energy technology potential and describes current opportunities and potential barriers, both technical and policy-related. This report does not assess transportation or the water sectors with regards to energy use; however they are called out as next steps.

The opportunities highlighted in this report can be used to help formulate an energy plan. The results are summarized below, and discussed in detail throughout the remainder of the report.

\section{General}

- Develop an outreach strategy

- Provide educational materials to the public

- Set priorities and develop specific goals to reduce fossil fuel consumption

- Develop a strategic energy plan

- Review energy policies, programs, and regulations

- Conduct a transportation evaluation

- Analyze water sectors as it pertains to energy use.

\section{Energy Efficiency}

- Provide training courses and materials for both architects and construction crews

- Create guidebooks and self-assessment checklists

- Evaluate and consider alternative cooling methods

- Perform energy and water audits and utilize the results to enhance the whole building environment. 


\section{Renewable Energy}

- Complete wind anemometry studies and analyze results

- Conduct detailed feasibility and economic assessments

- Identify available land area for renewable energy development

- Increase solar water heating implementation

- Consider potential of waste-to-energy.

Table 1 highlights current energy efficiency and renewable energy opportunities with estimated impact potential that a specialized team of experts at NREL have identified for the next step forward.

Table 1. Renewable Energy and Energy Efficiency Options with Potential Impact

\begin{tabular}{|l|l|}
\hline \multicolumn{1}{|c|}{ Opportunity Description } & \multicolumn{1}{|c|}{ Impact Potential } \\
\hline $\begin{array}{l}\text { Create a strategic plan to investigate and implement energy efficiency } \\
\text { and renewable energy where technically appropriate and feasible }\end{array}$ & High \\
\hline Increase energy efficiency standards in building codes & High \\
\hline $\begin{array}{l}\text { Further investigate and address the water system losses and efficiency } \\
\text { options }\end{array}$ & High \\
\hline Conduct transportation evaluation & High \\
\hline Evaluate and consider alternative cooling, such as cool-roof & Medium - High \\
\hline Assess the potential for solar hot water heating in different sectors & Medium - High \\
\hline Complete anemometer study: currently in process & Medium - High \\
\hline Increase energy awareness through island campaigns & Medium - High \\
\hline $\begin{array}{l}\text { Set an energy efficiency standard for island appliances and air } \\
\text { conditioning equipment }\end{array}$ & Medium \\
\hline
\end{tabular}




\section{Acronyms and Abbreviations}

A\&E Architecture and Engineering

ASPA American Samoa Power Authority

Btu British thermal unit

DOE U.S. Department of Energy

DOI U.S. Department of the Interior

EERS Energy Efficiency Resource Standard

EPA U.S. Environmental Protection Agency

FEMA Federal Energy Management Program

FY Fiscal Year

HECO Hawaiian Electric Company

$\mathrm{Hz} \quad$ hertz

IECC International Energy Conservation Code

$\mathrm{kV} \quad$ kilovolt

kVAR kilovolt-amperes reactive

kWhr kilowatt hour

lb. pound

m meter

MECO Maui Electric Company

$\mathrm{mi}^{2} \quad$ mile squared

MRF material recovery facility

MSW municipal solid waste

MVA megavolt ampere

MW megawatt

NPS National Park Service

NREL National Renewable Energy Laboratory

OIA Office of Insular Affairs 


$\begin{array}{ll}\text { ppm } & \text { parts per million } \\ \text { PV } & \text { photovoltaic } \\ \text { RDF } & \text { refuse derived fuel } \\ \text { RFP } & \text { Request for Proposals } \\ \text { RPS } & \text { Renewable Portfolio Standard } \\ \text { SEP } & \text { State Energy Program } \\ \text { TEO } & \text { Territorial Energy Office } \\ \text { TPD } & \text { tons per day } \\ \text { USDA } & \text { United States Department of Agriculture } \\ \text { Wp } & \text { Watt peak } \\ \text { WTE } & \text { waste-to-energy }\end{array}$




\section{Table of Contents}

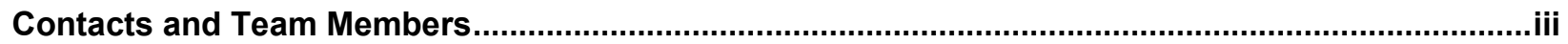

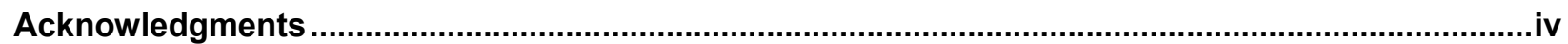

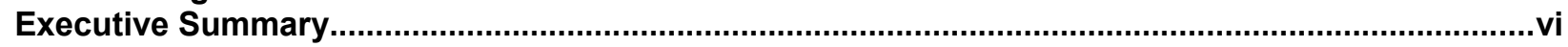

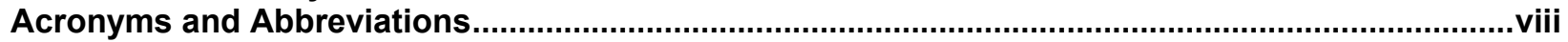

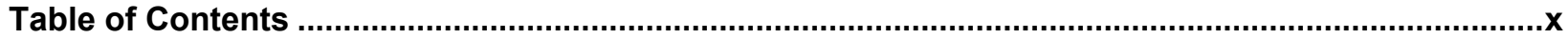

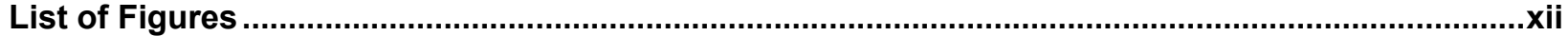

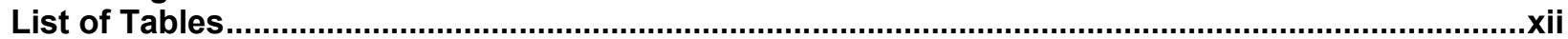

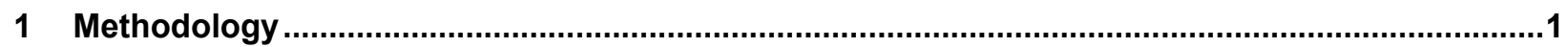

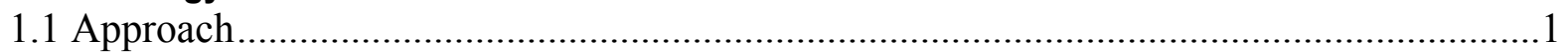

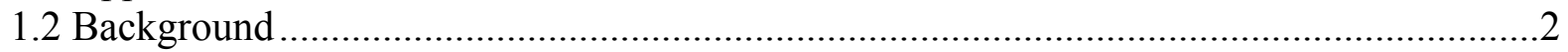

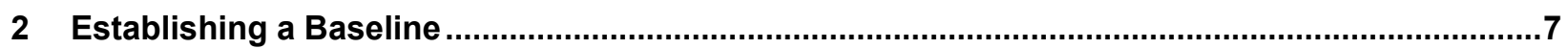

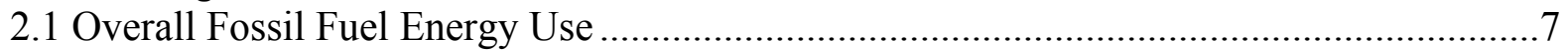

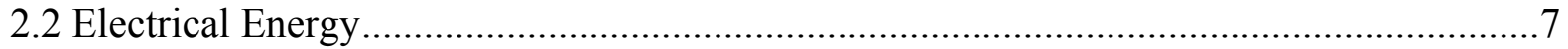

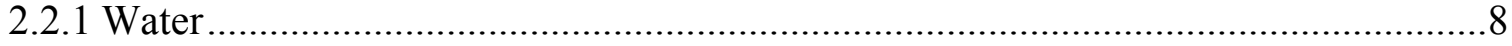

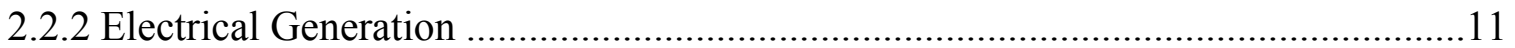

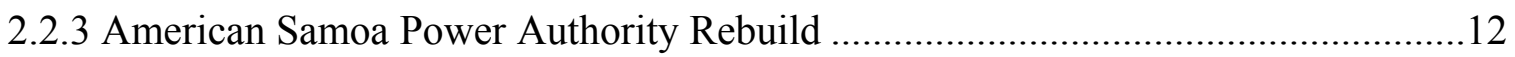

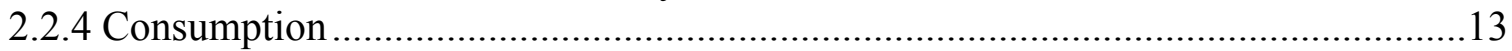

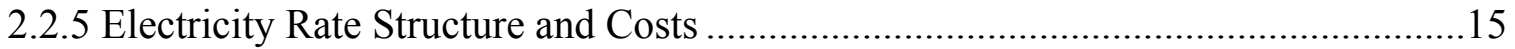

2.2.6 Maximum System Wide Renewable Energy Capacity .......................................16

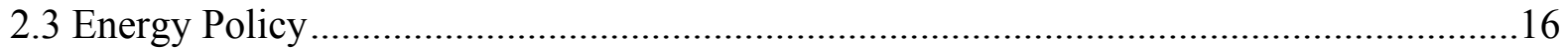

2.3.1 Electricity Rates Imbalance ......................................................................... 16

2.3.2 Communal Land Ownership Structure ......................................................... 16

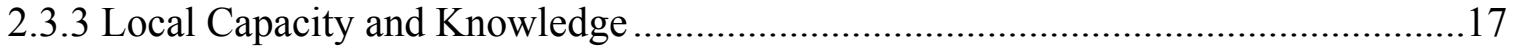

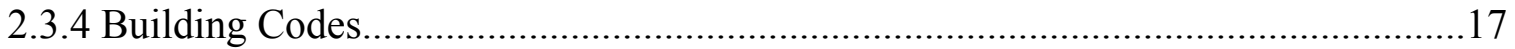

2.3.5 Net Metering Policy and Interconnection .................................................... 17

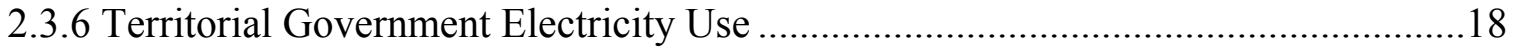

2.4 Solid Waste ...................................................................................................... 18

2.4.1 American Samoa Waste Generation and Composition Analysis...........................18

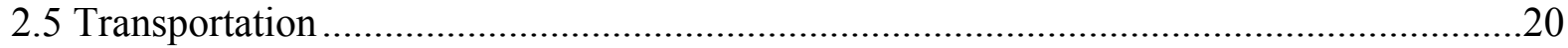

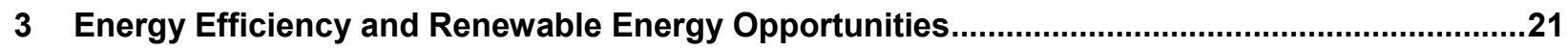

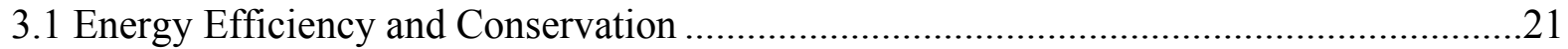

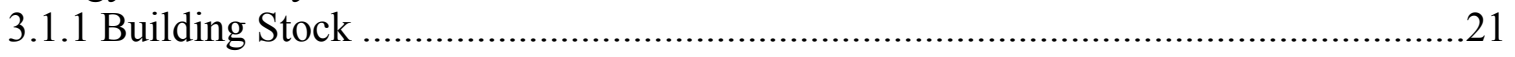

3.1.2 Review and Improve Energy Efficiency Standards to Improve Efficiency.............22

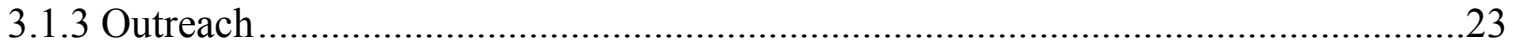

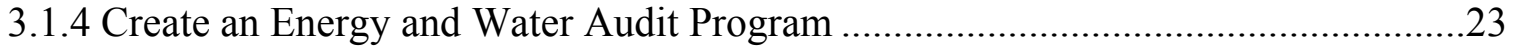

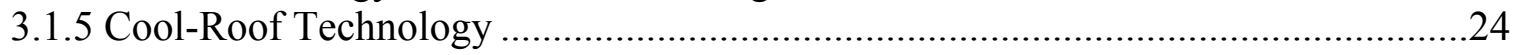

3.1.6 Energy Efficiency and Conservation Next Steps................................................24

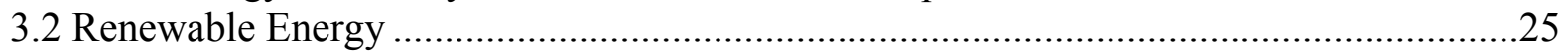

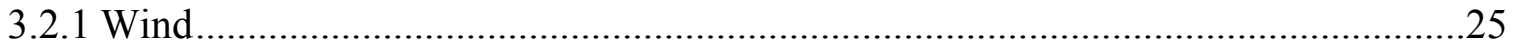

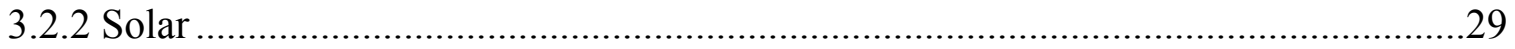

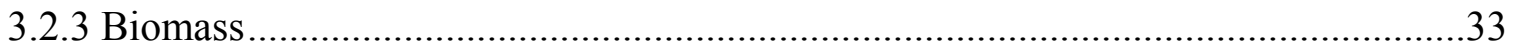

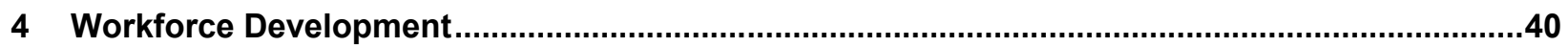

4.1 Workforce Development Next Steps ................................................................. 40

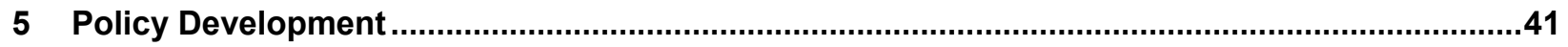

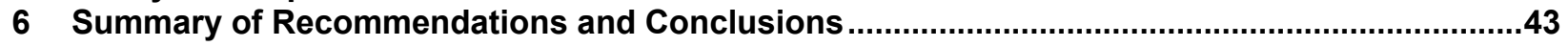

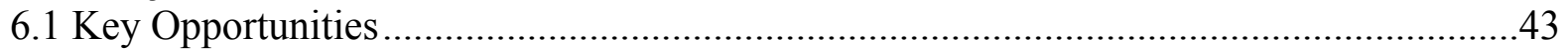

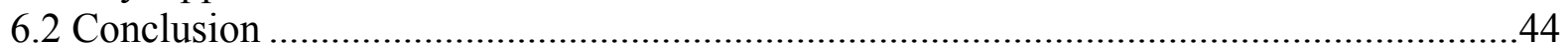




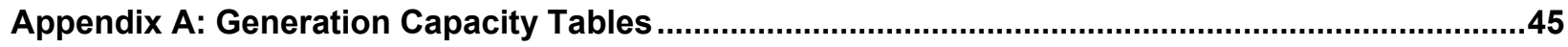

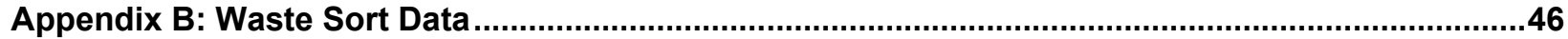

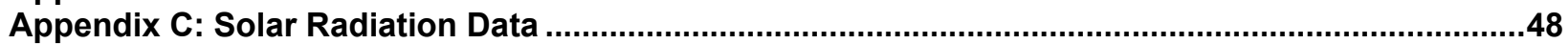

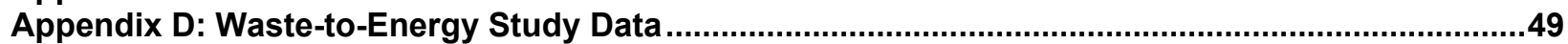




\section{List of Figures}

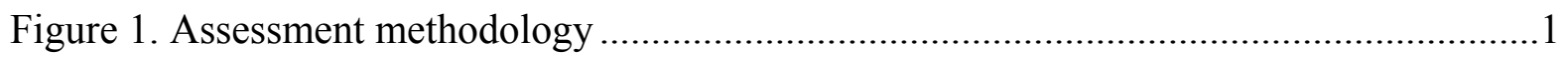

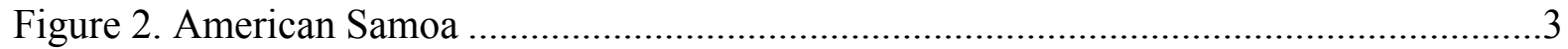

Figure 3. Tutuila, the main island of American Samoa ………………................................. 4

Figure 4. The Satala Power Plant, Tutuila, American Samoa prior to an earthquake and

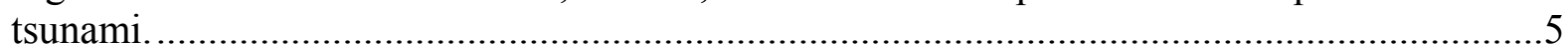

Figure 5. The Satala Power Plant Plant after an earthquake that resulted in a tsunami occurring on September 29, 2009................................................................................

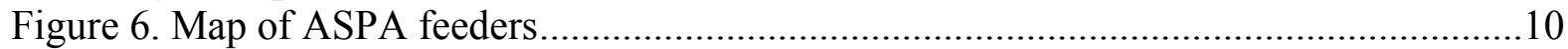

Figure 7. ASPA electric generation vs. fuel consumption data ...............................................12

Figure 8. Typical weekday load profile for Tutuila feeders - Monday December 13, 2010 ...14

Figure 9. Typical weekend load profile for Tutuila feeders - Sunday December 12, 2010.....14

Figure 10. Electrical consumption by sector........................................................................15

Figure 11. ASPA electricity rate structure - September 2010 ...............................................15

Figure 12. Waste composition developed by SCS engineers ...............................................19

Figure 13. Transit buses in Pago Pago, American Samoa ………………..............................2.

Figure 14. Cool roof tiles in colors other than white ……...............................................24

Figure 15. Anemometer study details .........................................................................26

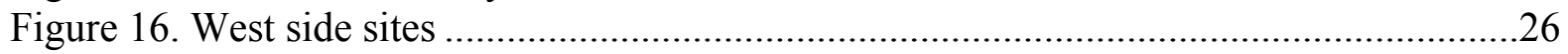

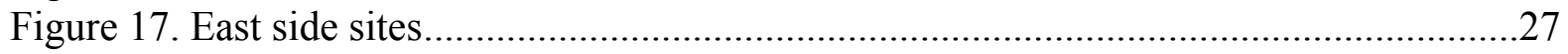

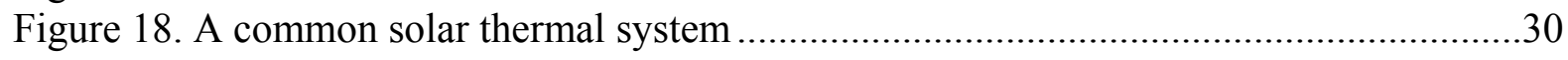

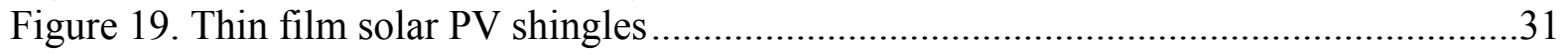

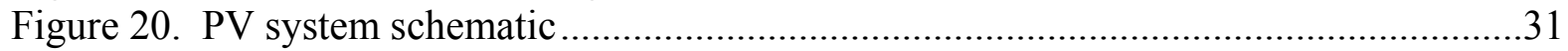

\section{List of Tables}

Table 1. Renewable Energy and Energy Efficiency Options with Potential Impact .............. vii

Table 2. American Samoa Employment Status ........................................................................

Table 3. Basic Power System Information for the Islands of American Samoa.......................... 8

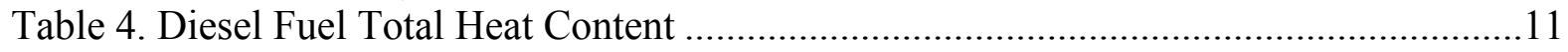

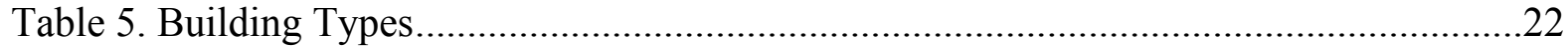

Table 6. Typical Efficiency of Different Types of PV cells ...................................................30

Table 7. Summary of Waste-to-Energy Potential ....................................................................... 34

Table 8. Pre-tsunami Generation Capacity (Before September 29, 2009) ………...................45

Table 9. Post-tsunami Generation Capacity, Tier II (Since Approximately December 2009) 45

Table 10. Annual Averages Based on Three-Week Data ......................................................46

Table 11. Most Prevalent Materials Identified by Waste Sort.................................................46

Table 12. Heat Rate Analysis for American Samoa ……….................................................4

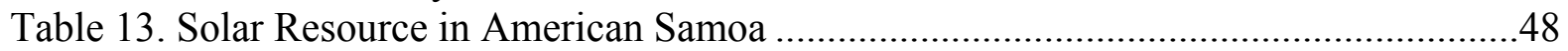

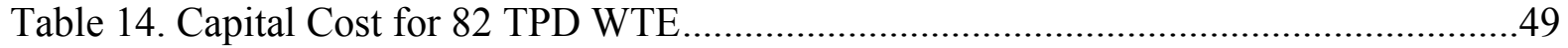

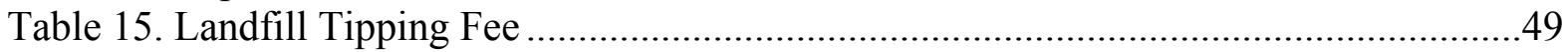




\section{Methodology}

The approach and background information used for this assessment are outlined in Sections 1.1 and 1.2.

\subsection{Approach}

Establishing the parameters of a study provides focus for the assessment team. Technologies were selected that are commercially available, ready for deployment, are a sound investment, and possible to finance.

Each assessment begins with a study of existing information and data to understand site demographics and geography. Human and physical geography impact energy consumption and the success of implementation of energy efficiency and renewable energy projects; therefore these characteristics are fundamental elements on which recommendations made.

Data collection and review of previous studies allows the assessment team to understand the current baseline consumption and what recommendations have been made in the past. Additionally, this research provides the team with information on what energy policies, programs, or projects are currently in place, as well as an understanding of those that have previously been attempted or implemented. The data collection process includes site visits to interview stakeholders and survey the options to include within the assessment. information is then analyzed and opportunities are identified.

Figure 1 illustrates the major components of NREL's assessment methodology.

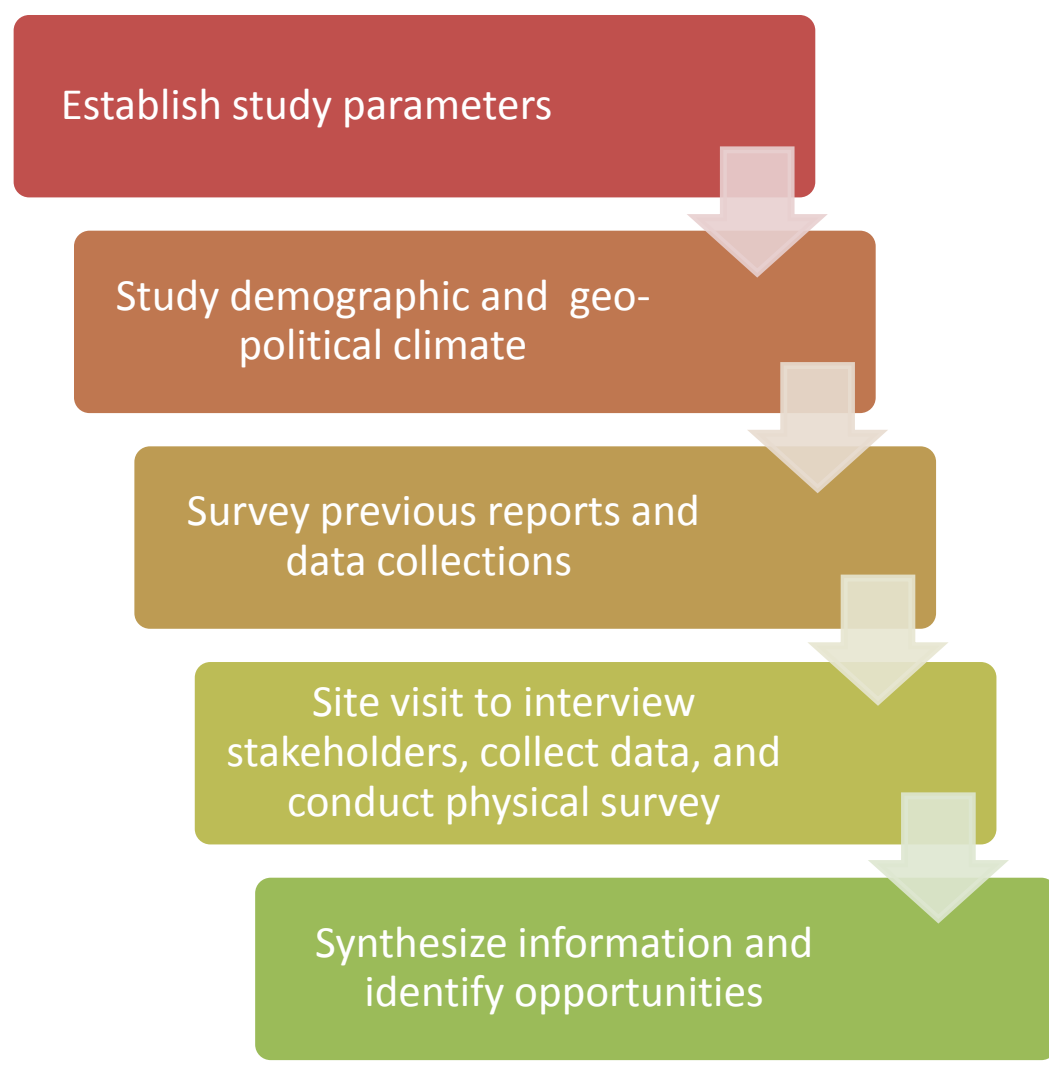

Figure 1. Assessment methodology

Source: NREL

There are many energy efficiency and renewable energy technologies on the market today; only 'bankable' or mature, commercially available technologies were considered. There are other technologies 
that American Samoa may decide to investigate in the future, but for the purpose of this assessment, technologies have met the following criteria:

- Commercially viable

○ Tested and demonstrated

- Carry warranty

○ Service and parts available

- Ready for immediate deployment

- Sound investment

- Financing available from private sector organizations

There are a number of conventional power generation options available to American Samoa, such as diesel and heavy fuel oil, and renewable energy technologies including solar, wind, biomass, and wasteto-energy (WTE). Each of these technologies has its own operational characteristics, initial and operational costs, implementation time horizon, and near and long term environmental impacts. Power generation choices require a large investment that can impact a community for many years. As such, any technology choice should be decided through careful analysis in the context of strategic long-term energy planning to ensure that the most appropriate choices are made for current and future generations. Potential costs underscore the importance of energy conservation and efficiency as a cost-effective method to reduce the investment needed for electricity generation.

This assessment focuses on commercial clean energy practices and technologies including conservation, energy efficiency, wind, solar, biomass, and WTE. NREL did not consider non-commercial renewable energy technologies such as ocean thermal energy conversion, off-shore wind, marine hydrokinetic, or other conventional power generation technologies such as nuclear, coal, or liquefied natural gas.

This assessment does not assess or analyze transportation or water sectors as it relates to energy use. These sectors are addressed minimally within their own sections and next steps are recommended.

This report summarizes data collected on energy production, consumption, and efficiencies based on information that is currently available. The assessment discusses renewable energy and energy efficiency technology potential as well as associated barriers and opportunities. Further investigation is needed to quantify the impact of specific technologies, programs, and/or projects. Environmental, regulatory, legislative, and financial considerations will need to be addressed during the energy planning and project development process.

\subsection{Background}

American Samoa is a group of five volcanic islands located in the South Pacific Ocean (roughly $14^{\circ} \mathrm{N}$ and $170^{\circ} \mathrm{W}$ ) approximately half way between Hawaii and New Zealand. American Samoa is an unincorporated territory of the United States. The President of the United States has assigned administration of American Samoa to the Secretary of the Interior. A map of American Samoa is provided in Figure 2. 


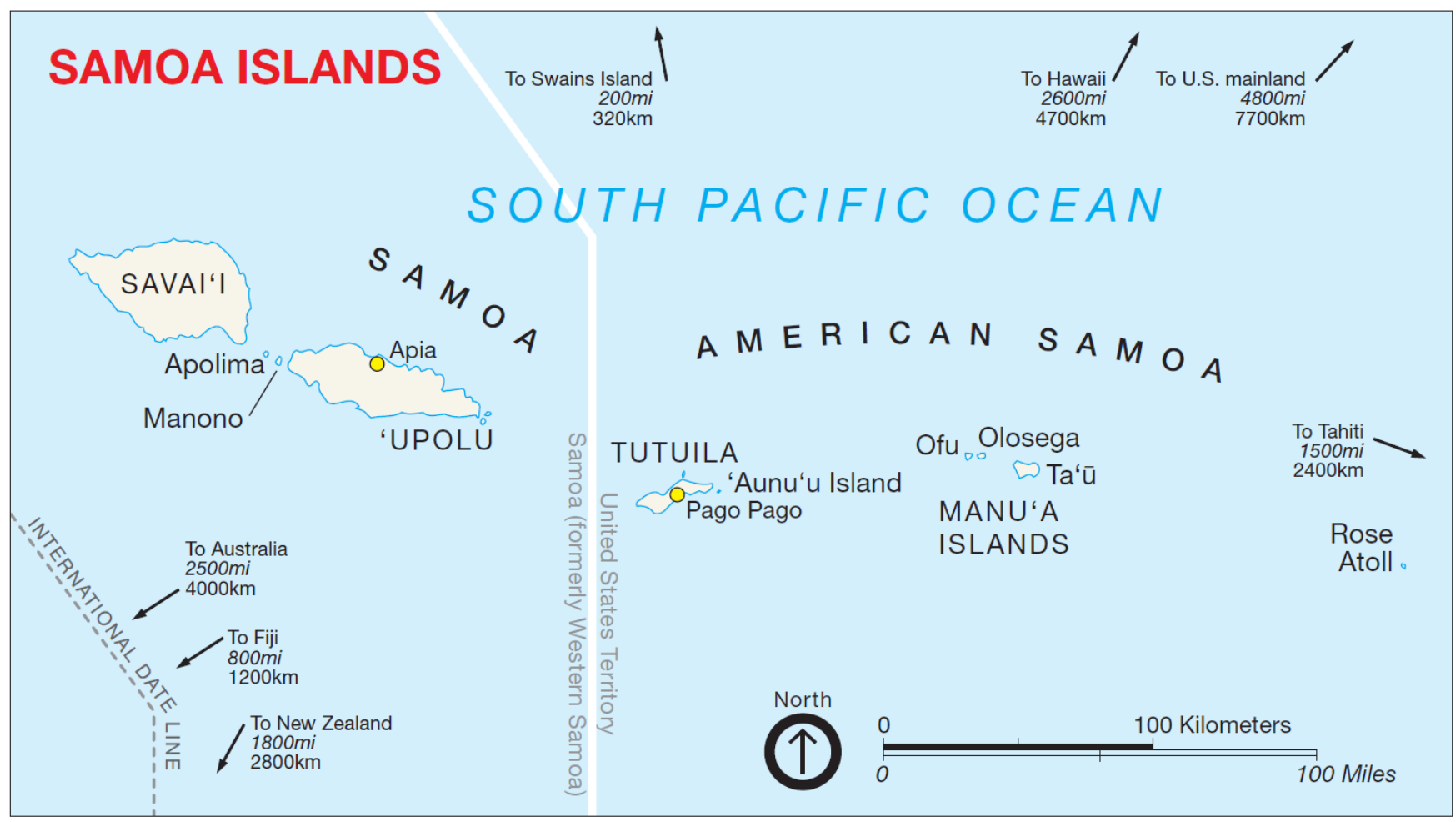

Figure 2. American Samoa ${ }^{1}$

American Samoa has five volcanic islands with limited coastline accessible to ships. There are two coral reefs that are part of the territory: Rose Island and Swains Island, which are low, tropical atolls. The total land area of American Samoa is 199 kilometers squared $\left(\mathrm{km}^{2}\right)$, or 76 square miles $\left(\mathrm{mi}^{2}\right)$, with 116 $\mathrm{km}$ (72 miles) of coast line. Natural hazards include susceptibility to typhoons between December and March. American Samoa has a tropical marine climate that is warm and humid with little seasonal temperature variation. The typical dry season occurs between May and October, and the rainy season is between November and April.

Tutuila is the major island of American Samoa, accounting for $69 \%$ of the $76 \mathrm{mi}^{2}$ of area (55 square miles) and $97 \%$ of the total population. The topography of Tutuila is rugged, volcanic terrain. An example of this terrain can is provided in Figure 3.

\footnotetext{
${ }^{1}$ http://home.nps.gov.
} 


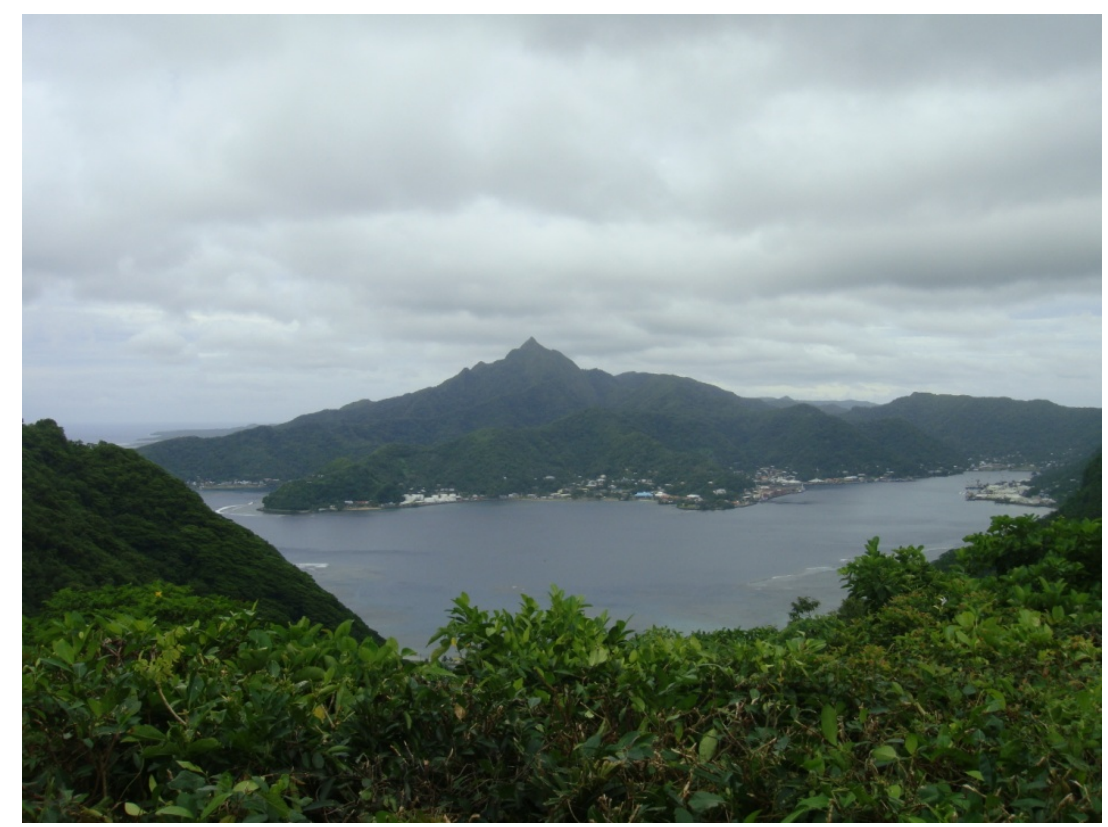

Figure 3. Tutuila, the main island of American Samoa

Source: NREL/PIX 19415

Aunu'u Island is located one mile off the southeastern shore of Tutuila and has a land area of 375 acres. It is a small volcanic island with a very small population.

The Manu'a group of islands, Ofu, Olosega, and Ta'u are approximately 70 miles east of Tutuila. They are high volcanic remnants located 14 degrees south of the equator. Similar to Tutuila and Aunu'u, the Manu'a Islands have a rugged, volcanic terrain.

American Samoa has a culturally diverse population. Ethnic groups include: Pacific Islander (91.6\%), Asian (2.8\%), Caucasian (1.1\%), mixed ethnicities (4.2\%), and other ethnic origins $(0.3 \%)$. In addition to English, languages include Samoa (90.6\%), Tongan (2.4\%), and others, mostly Asian (4.1\%). American Samoa has a literacy rate of 97\%. ${ }^{2}$ The population of American Samoa is 68,200 with an approximate annual growth of $2 \% .{ }^{3}$ Recent US Census reports show a decline in population by 10,000 .

American Samoa's land is 90\% communally owned in Polynesian tradition. The economic activities arise mostly in trade with the United States and tuna fishing and tuna processing. Canned tuna export has primarily been the backbone of the private sector. Two tuna canneries accounted for $80 \%$ of employment until one cannery closed in September 2009 due to financial restraints.

The current economy is dominated by local agriculture and one tuna cannery; however a tuna supply chain company, the Tri Marine Group, has begun renovations of a previously occupied tuna processing plant and is planning new operations in the near future.

Tourism is beginning to grow, but due to the limited amount of available land and infrequent flights and cruise ships, tourism is modest. The government is limited when trying to develop a broader economy by the islands' remote location, limited transportation, and reoccurring natural disasters such as typhoons. ${ }^{4}$

\footnotetext{
${ }^{2}$ CIA World Fact Book. www.cia.gov/library/publications/the-world-factbook/geos/aq.html.

${ }^{3}$ OIA. www.doi.gov/oia/Islandpages/asgpage.htm.

${ }^{4}$ CIA World Fact Book: https://www.cia.gov/library/publications/the-world-factbook/geos/aq.html.
} 
The estimated gross domestic product (GDP) is $\$ 483.1$ million, and the Per capita GDP is estimated at $\$ 7,084$. The tuna cannery employs between $27 \%$ and $28 \%$ of the workforce, with the government employing about a third. The employment status in American Samoa is summarized in Table 2. ${ }^{5}$

Table 2. American Samoa Employment Status

\begin{tabular}{|l|l|}
\hline Total employment (2007) & 17,047 \\
\hline Private sector employment & 10,995 \\
\hline Government employment & 6,520 \\
\hline Private Sector employment as a \% of total & $64.5 \%$ \\
\hline Government employment as a \% of total & $35.5 \%$ \\
\hline Unemployment rate (2005) & $29.84 \%$ \\
\hline
\end{tabular}

A powerful earthquake resulting in a tsunami hit American Samoa on September 29, 2009 (see before and after photos of the Satala Power Plant in Figures 4 and 5). The tsunami devastated American Samoa, disrupting transportation and power generation. The United States Federal Emergency Management Agency (FEMA) currently oversees relief programs totaling more than $\$ 100$ million.

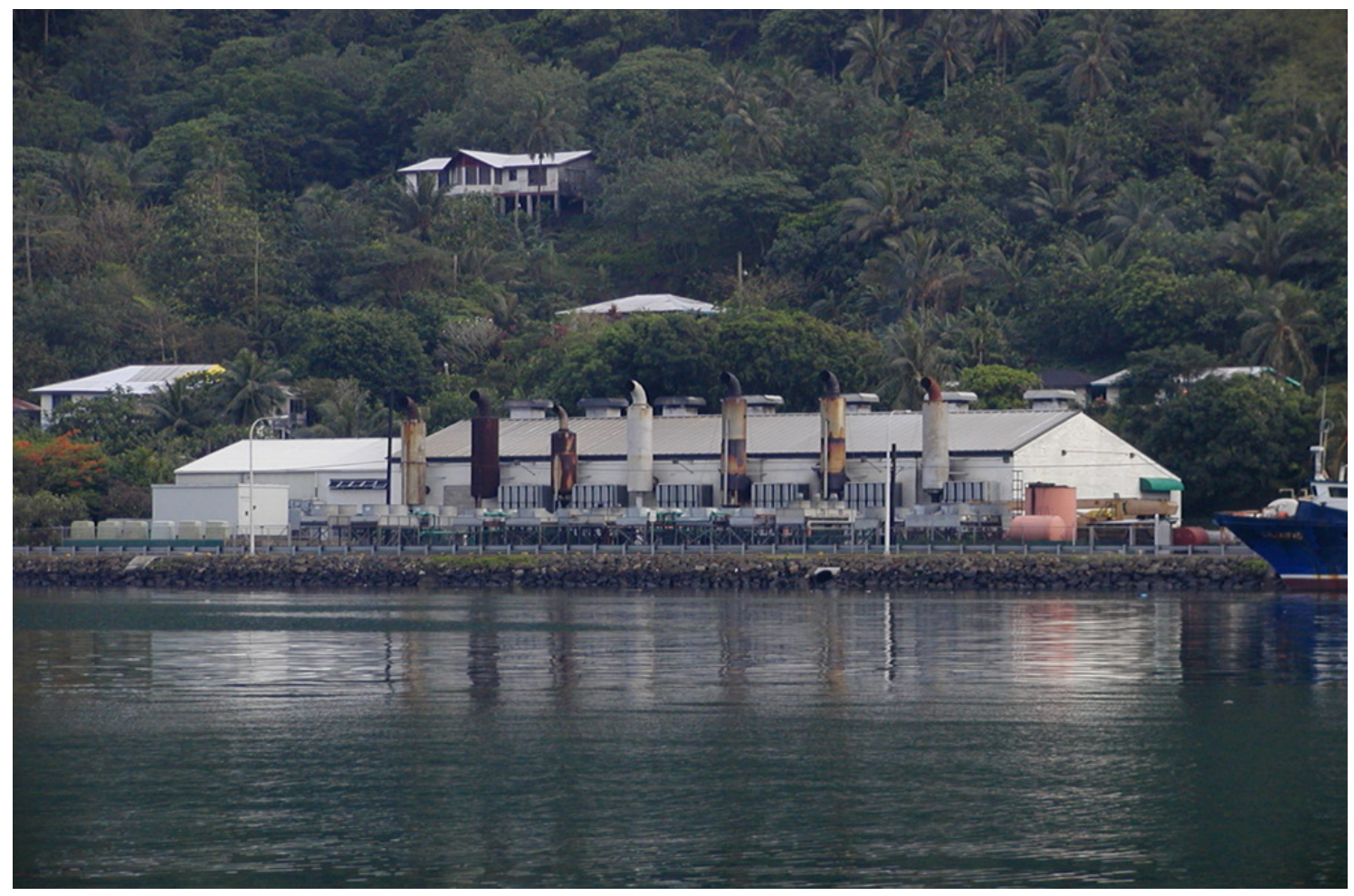

Figure 4. The Satala Power Plant, Tutuila, American Samoa prior to an earthquake and tsunami Source: NREL/PIX 19674

\footnotetext{
${ }^{5}$ OIA. www.doi.gov/oia/Islandpages/asgpage.htm.
} 


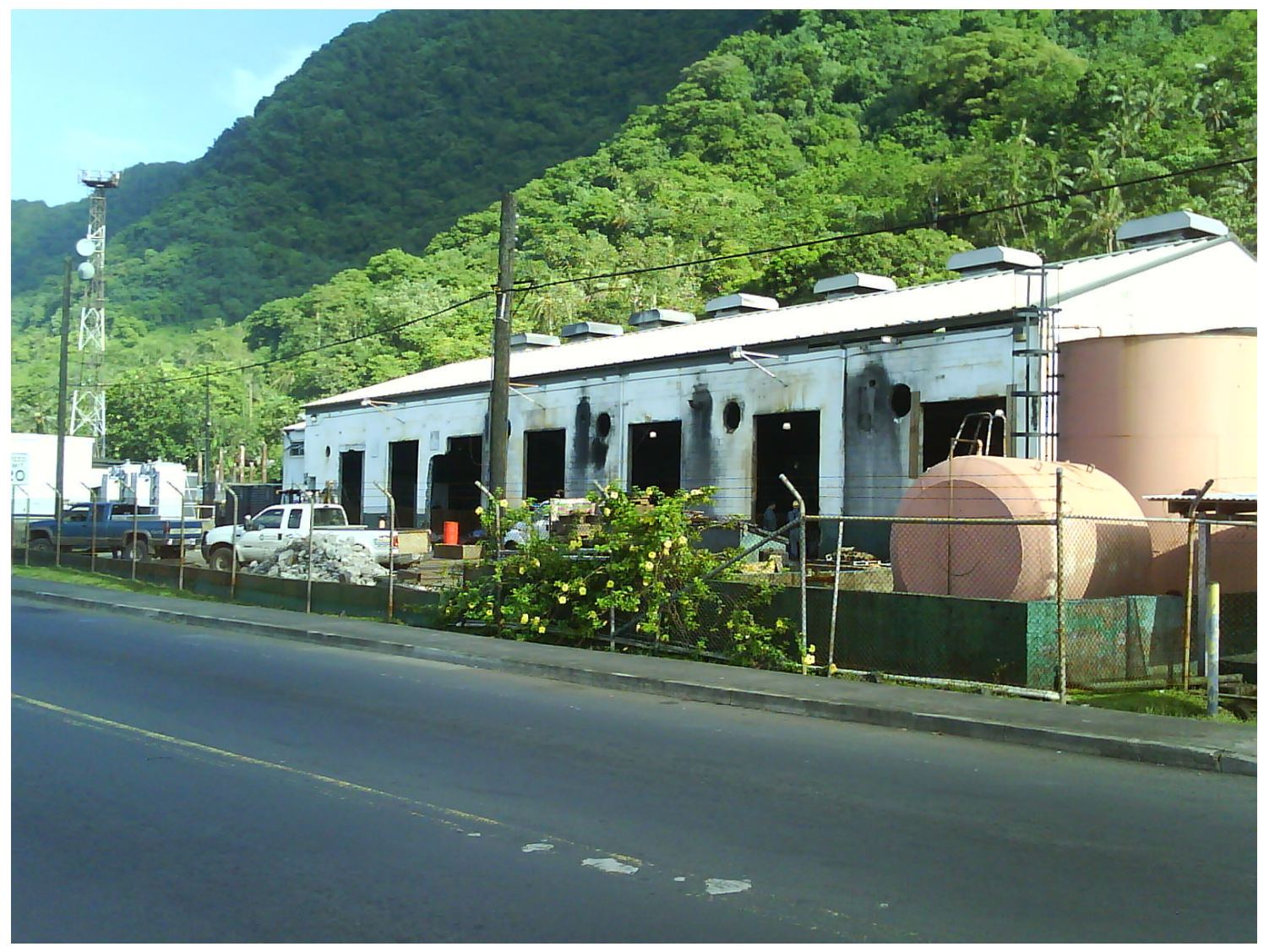

Figure 5. The Satala Power Plant Plant after an earthquake that resulted in a tsunami occurring on September 29, 2009

Source: NREL/PIX 19675 


\section{Establishing a Baseline}

Following a review of the natural and cultural influences, site assessments incorporate historical energy consumption data to establish the baseline. This section summarizes observations from electrical generation, end-use energy consumption and costs, and solid waste management. Additional details are provided in the appendices.

\subsection{Overall Fossil Fuel Energy Use}

The American Samoa Power Authority (ASPA) is the only utility operating in American Samoa. It is an entity of the government and serves about 12,000 customers in two districts. ASPA provides electricity, domestic water, wastewater, and solid waste services and in 2008 became a fuel supplier. ASPA is directed by a five member board, nominated by the governor and confirmed by AS legislature and administered by the Chief Executive Officer.

With the exception of a few small renewable energy projects, American Samoa is currently almost $100 \%$ dependent on imported fossil fuels for its energy supply needs. The primary areas of fossil fuel consumption are:

- Electricity production

- Transportation

- Space cooling

- Water heating

- Water distribution.

\subsection{Electrical Energy}

ASPA serves about 12,000 customers. The ASPA electrical distribution system on Tutuila operates at a nominal 13.2 kilovolts $(\mathrm{kV})$. ASPA services two substations, approximately 170 miles of 13.2-kV lines, and 1,560 miles of low-voltage lines. There are a few underground feeders on the island, but most are overhead due to financial constraints. Because of the relatively small size of the island, there is no transmission system per se, but there is a single $34.5-\mathrm{kV}$ tie line between the Tafuna and Satala power plants (Figure 6). The tie line is 9.5 miles long with 4/0 gauge copper underground cable in duct. The Tafuna plant is located on the western side of the island mainly manages airport and residential loads. The Satala plant is located among the more industrial (tuna canneries) and commercial (government building) loads along Pago Pago Harbor. A summary of basic power system information for the islands of American Samoa can be seen in Table 3. Detailed information related to each generator can be found in Appendix A: Generation Capacity Tables. 


\begin{tabular}{lll}
\hline & Tutuila & Manu'a \\
$\begin{array}{l}\text { Installed Capacity (diesel } \\
\text { power) }\end{array}$ & $39 \mathrm{MW}$ & $1.6 \mathrm{MW}$ \\
Peak Load & $23.1 \mathrm{MW}$ & $0.31 \mathrm{MW}$ \\
Base Load & $18 \mathrm{MW}$ & $0.22 \mathrm{MW}$ \\
$\begin{array}{l}\mathbf{2 0 1 5} \text { Peak Load Forecast } \\
\text { (1 to 2\% growth) }\end{array}$ & $26.5 \mathrm{MW}$ & $0.32 \mathrm{MW}$ \\
$\begin{array}{l}\text { Current Customers (FY } \\
\text { 2010) }\end{array}$ & 11732 & 152 \\
\hline
\end{tabular}

To reduce line losses and improve reliability, ASPA is currently constructing a new Feeder 10 to serve the villages on the west side of the island, west of Leone. Feeder 10 will serve Futiga to Fagamalo on the western side of island. Materials arrived on island April 2011 and the project is scheduled to be completed by the end of 2011. Since most of the electric loads on this new feeder are residential and Feeder 9 is mixed use, the $600 \mathrm{kVAR}$ fixed capacitor bank will be removed from Feeder 9 and moved to Feeder 10. ASPA's line losses are presently just above $8 \%$.

\subsubsection{Water}

A significant amount of energy is required to pump and treat potable water, and to collect, pump, and treat wastewater. Reducing water consumption and improving the efficiency of water pumping systems reduces overall fuel use and energy costs.

Potable water in American Samoa comes from 53 wells and two reverse osmosis units. Rates for residential and commercial customers are tiered from volume usage for residential customers (rates shown below, does not include commercial customers). Full rates can be found on ASPA's website, www.aspower.com.

Base water rates are calculated on a use per thousand gallons basis as shown in the table below ${ }^{6:}$

\footnotetext{
${ }^{6}$ American Samoa Administrative Code, Title 12, Chapter 03.
} 


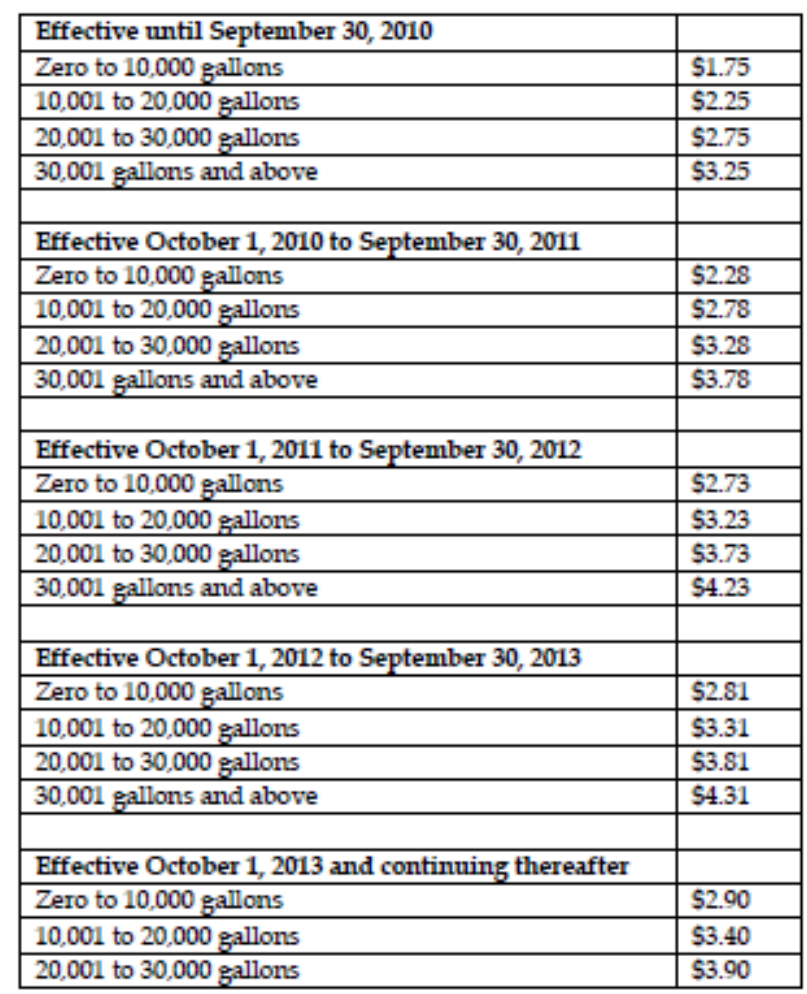

Commercial customers are charged a flat base rate of $\$ 2.45$ per 1,000 gallons plus the pump fuel surcharge that varies monthly. For the month of July, commercial customers were charged $\$ 3.88$ per 1,000 gallons ( $\$ 2.45$ per 1,000 gallons $+\$ 1.43$ pump fuel surcharge).

The total energy use for water and wastewater services in American Samoa was not determined for this report, but should be considered as part of the energy planning effort. Water conservation and efficiency may significantly reduce costs due to high water rates, and reduce overall energy and fuel consumption. ASPA estimates that almost $50 \%$ of non-revenue water is unaccounted for.

Understanding where losses reside and investigating opportunities to improve pumping efficiency presents an opportunity to lower energy expenses. 


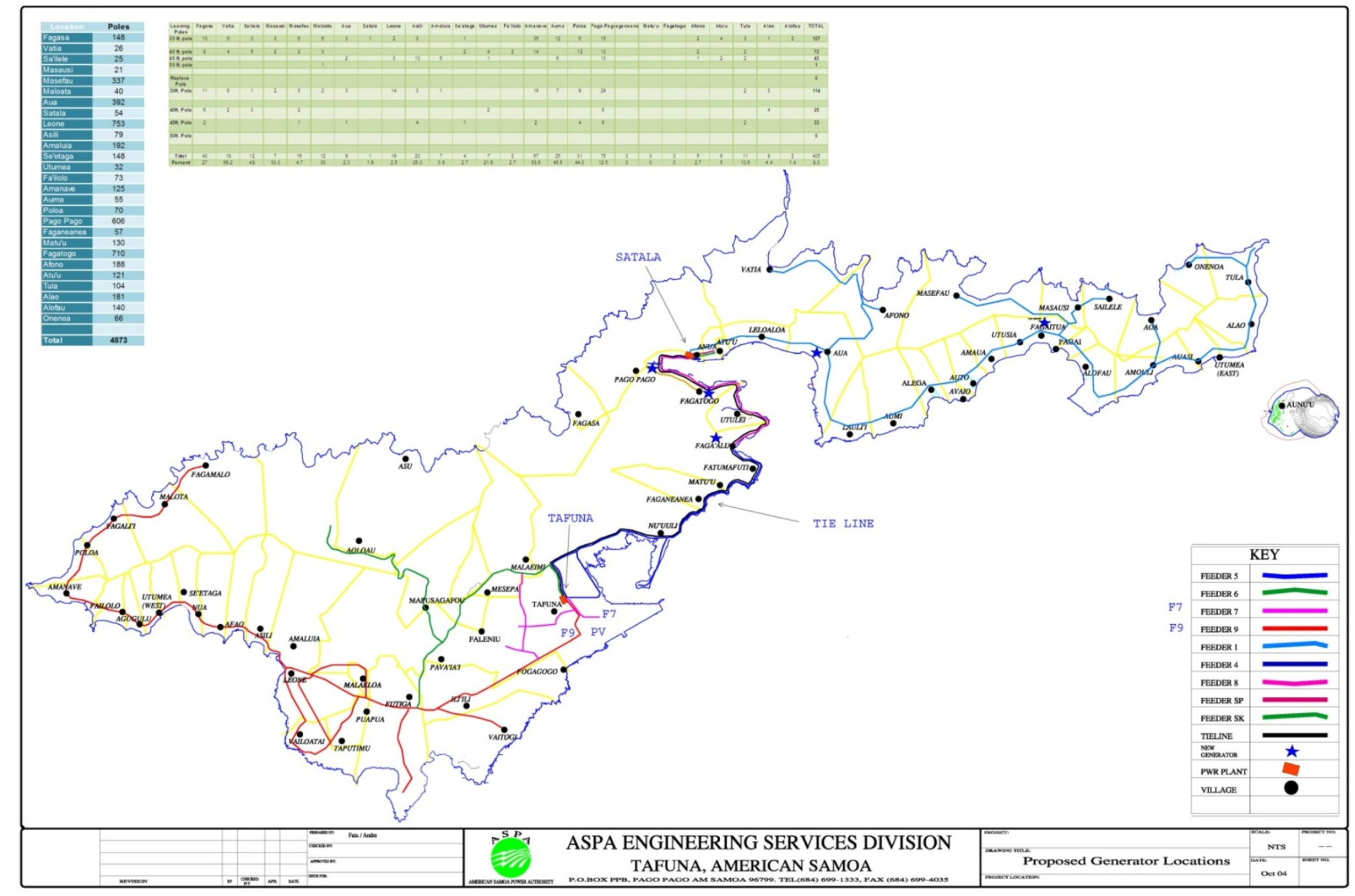

Figure 6. Map of ASPA feeders ${ }^{7}$ 


\subsubsection{Electrical Generation}

ASPA generation inventory is almost $100 \%$ diesel powered reciprocating engines, or gensets with limited small renewable energy projects. The generation and fuel-consumption for the 11 years between 2000 and 2010 are plotted in Figure 7. There is a slow decrease in the efficiency (British thermal units per kilowatt hour, Btu/kWh) from 2000 to 2009. The more significant drop in efficiency in 2009 is due to the lower operating efficiency of the temporary generators brought online after the September 2009 tsunami. The "Overall System Heat Rate" plot is based on an energy density of 138,690 Btu per U.S. gallon of diesel ${ }^{8}$. It is simply converting the amount of energy consumed to Btu, and dividing by the amount of energy generated. ASPA uses diesel No. 2 to run its generators. Diesel No. 2 fuel specification (at 2000 parts per million, ppm) is found below in Table 4.

Table 4. Diesel Fuel Total Heat Content ${ }^{9}$

\begin{tabular}{|l|l|}
\hline API Gravity & $\begin{array}{l}\text { Total Heat Content } \\
\text { BTU per barrel }\end{array}$ \\
\hline $\mathbf{3 5}$ & $\mathbf{5 , 7 4 2 , 2 4 0}$ \\
\hline $\mathbf{3 6}$ & $\mathbf{5 , 7 1 7 , 4 6 0}$ \\
\hline $\mathbf{3 8}$ & $\mathbf{5 , 6 6 8 , 3 2 0}$ \\
\hline
\end{tabular}

There are several reasons fuel efficiencies dropped in American Samoa over the years ${ }^{10}$ :

1. The aging of the base-load Deutz engines (some have been in service more than 15 years)

2. ASPA was using 5,000-ppm sulfur No. 2 diesel until 2005, when the U.S. Environmental Protection Agency (EPA) mandated ASPA use 2000-ppm sulfur to reduce air pollutant levels. The average energy decrease per gallon by switching to the lower-sulfur diesel is about 700 Btu per gallon.

3. The tsunami of September 2009 took several generators offline, and ASPA accepted lower efficiency temporary gensets from Aggreko.

\footnotetext{
${ }^{8} \mathrm{http} / /$ hypertextbook.com/facts/2006/TatyanaNektalova.shtml.

${ }^{9}$ E-mail communication with Joachim Fong, ASPA Engineering Service.

${ }^{10}$ E-mail communication with Joachim Fong, ASPA Engineering Service.
} 


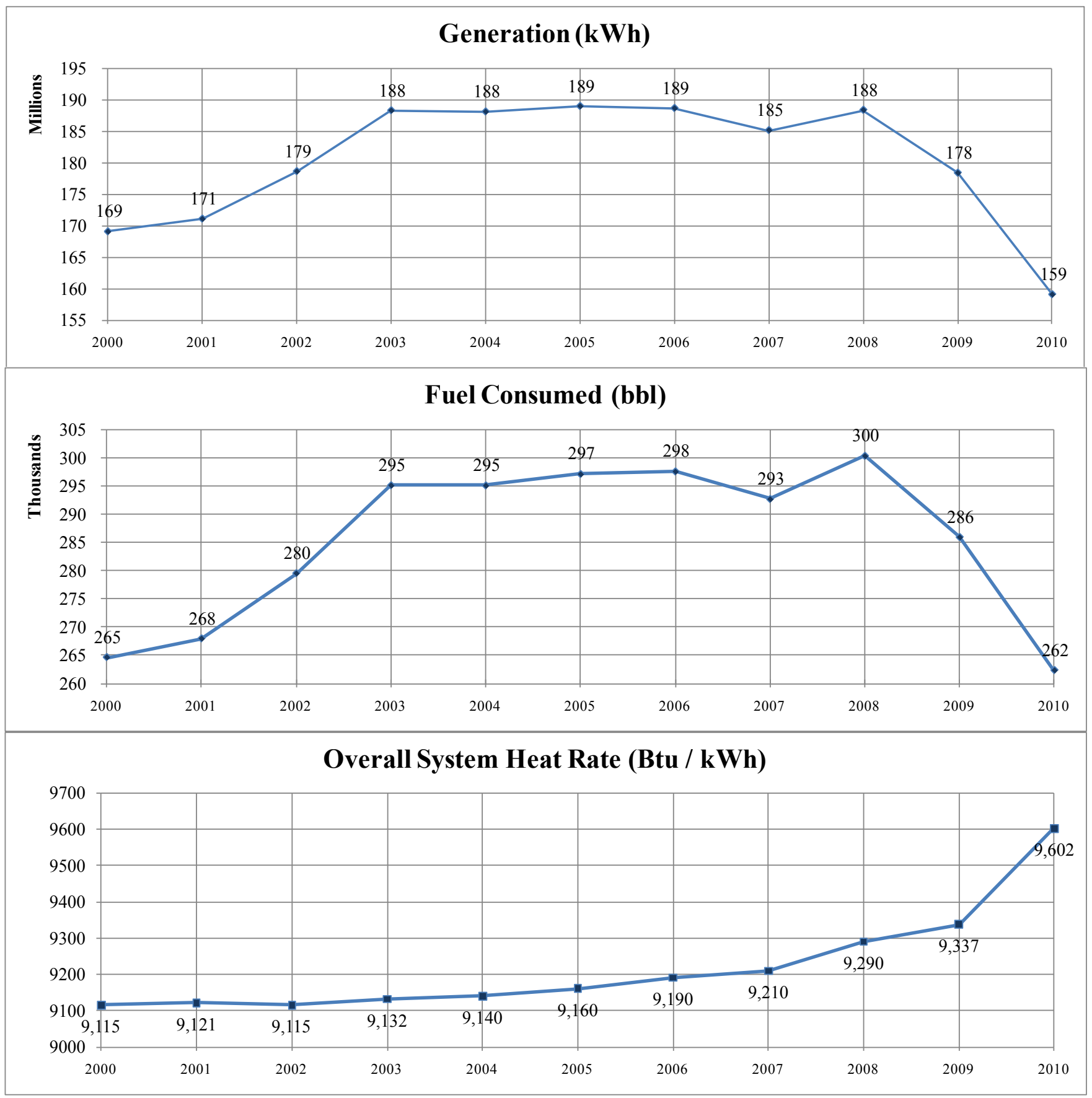

Figure 7. ASPA electric generation vs. fuel consumption data ${ }^{11}$

\subsubsection{American Samoa Power Authority Rebuild}

More than half of the island's generation capacity (specifically the entire Satala plant, or 23 megawatts, [MW], of $45 \mathrm{MW}$ ) was destroyed during the earthquake and tsunami that hit on September 29, 2009. With FEMA's assistance, ASPA installed twenty-seven 1-MW temporary Aggreko generators with a rated capacity of $24 \mathrm{MW}$, leasing them at $\$ 760,000$ per month. The old generators were derated due to ambient heat and age. ASPA keeps enough excess capacity to cover a generator outage while also repairing other generators. Since the tsunami, FEMA covers $90 \%$ of the rebuild costs, while ASPA covers $10 \%$. All temporary generators will be replaced for $\$ 16$ million. Because the temporary generators are inefficient, and ASPA is responsible for the fuel, ASPA is spending more than originally budgeted. 
FEMA and ASPA developed a three-tiered plan for power following the September 2009 tsunami. Tier 1 was based on use of 56 FEMA-supplied and five ASPA-supplied temporary generators immediately following the disaster. Tier 2 (initiated in approximately December 2009) involves the use of a temporary power generation system (Aggreko). Tier 3 (occurring approximately three to four years after the disaster) is the permanent project with a total capacity of $23 \mathrm{MW}$ diesel generators.

In addition to the new generation, ASPA is planning to upgrade the 9.5-mile tie line between Satala and Tafuna (Figure 6). The transformer in Satala for the tie line was knocked out but the tie line itself survived intact. Two 5-megavolt ampere (MVA) transformers along with associated switchgear will be installed in parallel at both Satala and Tafuna for redundancy. The existing $34.5-\mathrm{kV}$ underground cable, which was not damaged, will interconnect the two power plants.

Through a Department of Energy (DOE) American Recovery and Reinvestment Act (ARRA) grant facilitated by the Territorial Energy Office (TEO), a request for proposal (RFP) was issued in December 2010 for a ground-mounted grid-tied PV system for a total cost of $\$ 8.5$ million, to be located on 3.75 acres adjacent to the airport runway. The PV turnkey project contract was awarded in July 2011 for the installation of 1.5-MW capacity output. The new PV system at the airport will be split into two subarrays and will interconnect to Feeder 7 and Feeder 9, each taking an output of 750-kW. The PV system will be less than half a mile from the Tafuna power plant. Feeder 7 has no voltage regulators or capacitor banks. Feeder 9 has a 600-kilovolt-ampere reactive (kVAR) fixed capacitor bank to improve voltage profile and is the only voltage regulator on the island, located at Leone due to the long feeder length. Both Feeder 7 and Feeder 9 are overhead feeders. There is a high concentration of water pumps in the range of 30 to 40 horsepower on the two feeders. Presently Feeder 9 is over utilized at more than $90 \%$. By the end of 2011 it is expected that a new express feeder, Feeder 10, will divert half of the load from Feeder 9, after which the capacitor bank will be removed. Feeder 10 will pick up the load on the west side of the island, from Futiga to Fagamalo.

Additionally, through another ARRA grant, ASPA awarded a contract to install an Organic Rankine Cycle (ORC) system that will generate electricity from the waste heat produced through a high temperature jacket water system from the base load diesel generators at the Tafuna Power Plant.

\subsubsection{Consumption}

Figure 8 and Figure 9 show the load profiles for the four feeders supplied by the Tafuna power plant. ${ }^{12}$ The figures show a typical load profile for a weekday and weekend day. Because of the hot, humid, tropical climate, the load profile does not vary much seasonally. Curiously unexplained is the increase in the evening. On a typical weekday the load on Feeder 7 varies between 2,100 kW and 3,275 kW (a difference of $36 \%$ ) and varies between $2,250 \mathrm{~kW}$ and 3,200 $\mathrm{kW}$ (a difference of $30 \%$ ) on a typical weekend day. On a typical weekday the load on Feeder 9 varies between 2,450 kW and 4,225 kW (a difference of $43 \%$ ) and varies between 2,500 $\mathrm{kW}$ and 3,875 $\mathrm{kW}$ (a difference of 35\%) on a typical weekend day. The new solar PV system being installed at the airport will be divided into two subarrays and tie into Feeders 7 and 9.

The largest consumer sector is residential with 45,269 MWh sold to 10,475 meters. In Fiscal Year (FY) 2010, the average monthly use per residential customer was $360 \mathrm{kWh}$. Commercial average monthly use per meter was 4,018 kWh. Large power used 342,924 kWh per meter. The American Samoa Government used 2,201 MWh per month, and ASPA used $746 \mathrm{MWh}$ per month. The consumer breakout can be seen in Figure 10.

\footnotetext{
${ }^{12}$ ASPA Engineering Services.
} 


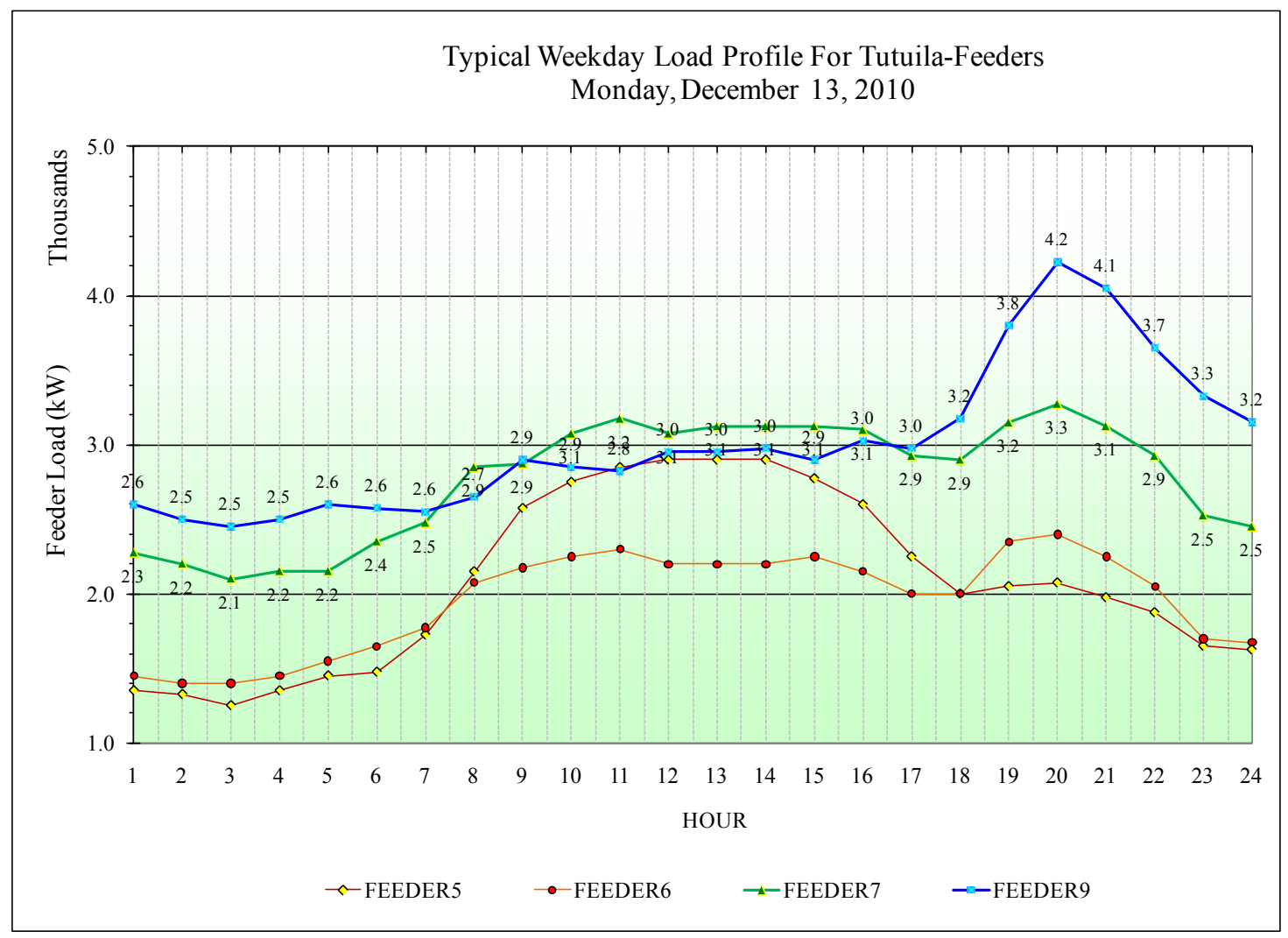

Figure 8. Typical weekday load profile for Tutuila feeders - Monday December 13, $2010^{13}$

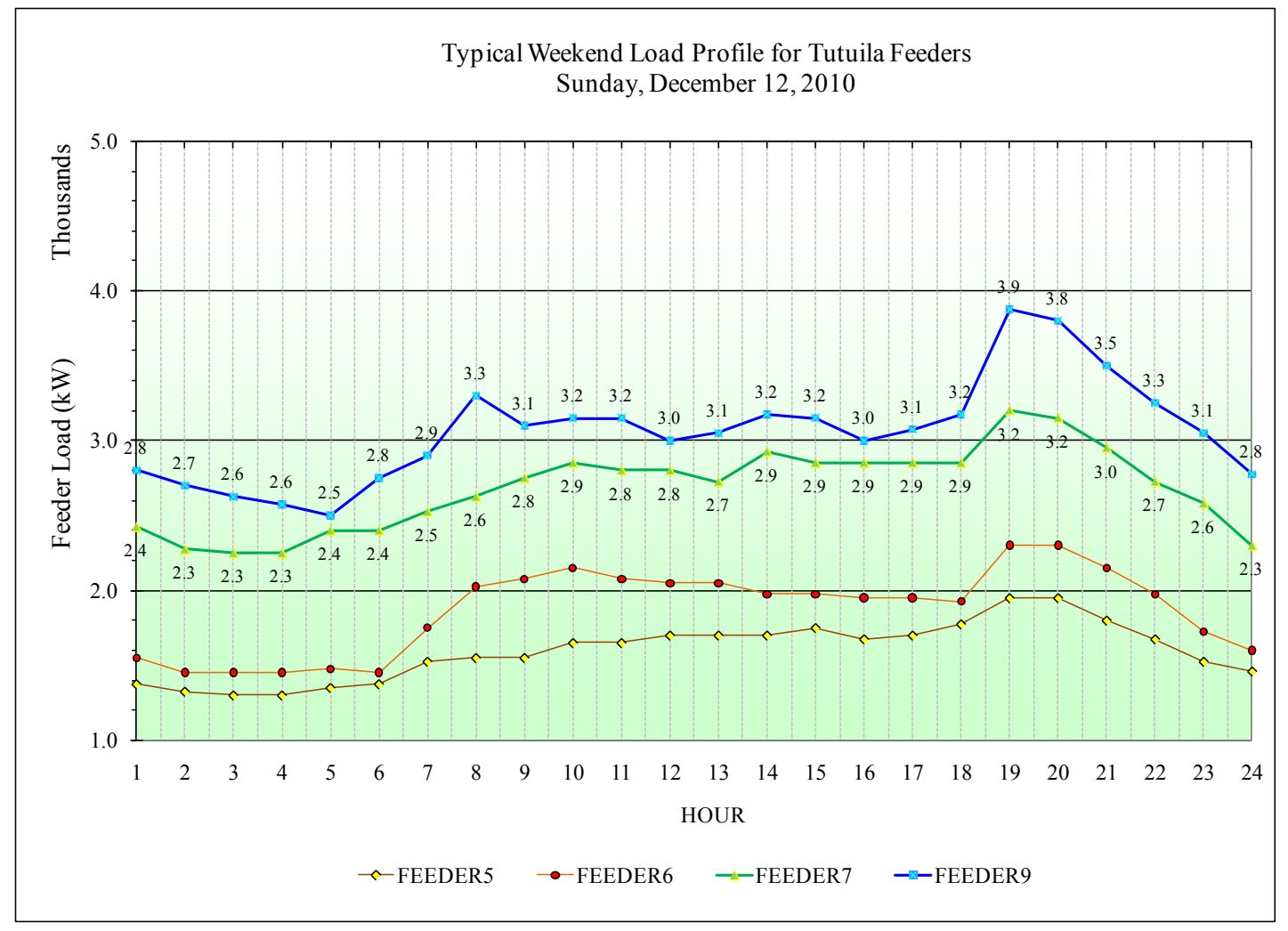

Figure 9. Typical weekend load profile for Tutuila feeders - Sunday December 12, $2010^{14}$

${ }^{13}$ Ibid.
${ }^{14}$ Ibid. 


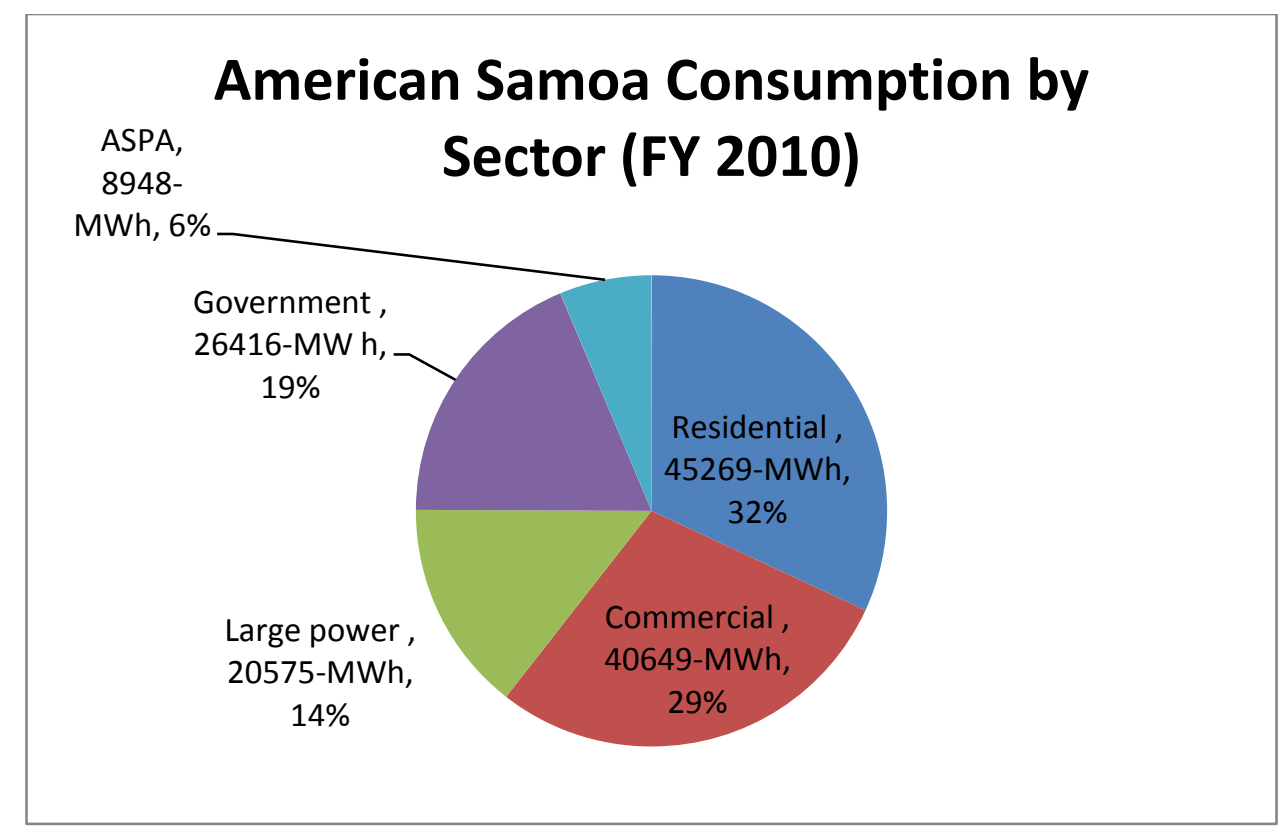

Figure 10. Electrical consumption by sector

Source: NREL

\subsubsection{Electricity Rate Structure and Costs}

The cost of electricity for residential, small commercial and large commercial customers was approximately $\$ 0.31 / \mathrm{kWh}$ when measured in September 2010 (Figure 11). ${ }^{15}$ The rate for "large power" or industrial customers such as fish canneries is negotiated. The fuel surcharge (based on the Means of Platts Singapore) is adjusted by the American Samoa Government Office of Petroleum Management into a maximum allowable price, much like the levelized energy adjustment clause in Guam and the Commonwealth of the Northern Mariana Islands. As is the case for all Pacific Island countries, the price of electricity in American Samoa is mainly a function of the volatile world price of diesel fuel. Fuel surcharges are used to recover the cost of fuel. Fuel prices more than doubled from 2006 to 2008. The world price of diesel decreased in 2009 after a worldwide recession.

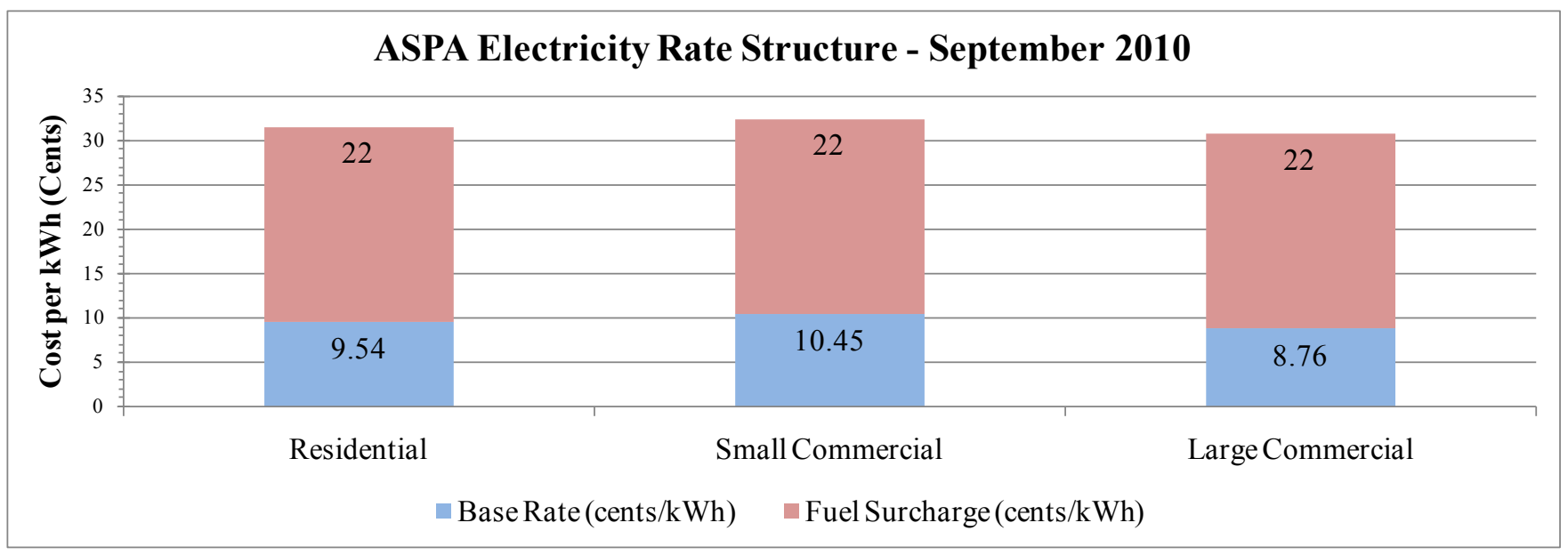

Figure 11. ASPA electricity rate structure - September $2010^{16}$

During NREL's visit in November 2010, the Tafuna power plant frequency seemed to be running high at 60.29 hertz $(\mathrm{Hz})$. Not only did the frequency indicator at the power plant read high, but electronic

\footnotetext{
${ }^{15}$ ASPA Energy and Financial Security presentation, November 2010.

${ }^{16}$ ASPA Energy and Financial Security presentation, November 2010.
} 
analogue clocks on the island were running several minutes fast, most likely due to the higher utility frequency. Lowering the frequency might lead to some efficiency increases. High frequency could be an indication that generation is in excess of the load. Excessive frequency excursions, greater than $+/-$ $0.5 \mathrm{~Hz}$, could also cause PV inverters to trip offline. ASPA would not receive complaints because residential PV owners would have no method to determine if their PV is working.

\subsubsection{Maximum System Wide Renewable Energy Capacity}

ASPA has set the maximum allowable renewable energy on the system at $20 \%$ of peak demand capacity to ensure it can provide reliable service. However, the $20 \%$ maximum has been set based on a generalization and is not necessarily specific to the capabilities and needs of the American Samoa grid. An interconnection study would provide the necessary information to determine the true technical limits of the grid. Additionally, it remains uncertain as to whether or not there is also a $20 \%$ set maximum of peak demand capacity on individual feeder lines.

\subsection{Energy Policy}

Policy is one of the mechanisms that governments can use to establish an environment that is supportive of energy efficiency and renewable energy technologies. If designed properly, territorial policies, like state level policies, can drive market adoption, provide market certainty for investors and help to achieve a community's energy security, economic development, and environmental protection goals. Developing an appropriate policy environment builds the foundation for a community to achieve short-, mediumand long-term goals.

American Samoa historically has had few policies specific to energy efficiency and renewable energy. Even with a relatively high cost of energy, the market for energy efficiency and renewable energy technologies has not grown rapidly. Recently, however, the territory has begun to implement policies to address barriers to energy efficiency and renewable energy by sending a stronger market signal of government support for the industries. The following sections briefly describe the current policy environment and the broader issues that impact energy efficiency and renewable energy deployment.

\subsubsection{Electricity Rates Imbalance}

Electricity rates are the same on all American Samoa islands, although the cost to deliver the electricity on outer islands is substantially more expensive than it is on the main island of Tutuila. While the subsidization of electricity rates for those living on the outer islands allows for equitable costs across society, it disincentivizes energy efficiency improvements and renewable energy projects on the outer islands that would be cost effective if customer rates more accurately reflected the cost of electricity. Distributed renewable energy projects would likely be good candidates for addressing the energy needs on the outer islands and remote areas on Tutuila, but the disconnect created by the current electricity rate structure creates an imbalance between the economics of conventional energy sources (e.g. diesel generation) and renewable sources. This imbalance serves as a barrier to renewable energy development.

\subsubsection{Communal Land Ownership Structure}

One potential barrier to the development of large-scale renewable energy projects results from the difficulties in acquiring land leases for longer than 5 to 10 years. While this is not an energy-specific policy, the fact that land is owned communally may impede the development of renewable energy projects and is important to recognize when considering the development of any privately funded renewable energy projects. The economics of most large-scale energy projects, renewable or conventional, require project life spans that are longer than 5 to 10 years. The inability to enter into a long-term (e.g. 20 year) land lease creates a greater risk for renewable energy project developers because they cannot be certain of the costs associated with the land-lease in the project's later years. The limited lease time will serve as a barrier to renewable energy development. 


\subsubsection{Local Capacity and Knowledge}

Many stakeholders identified a lack of local capacity for installing and maintaining clean energy technologies as a barrier to deployment of energy efficiency and renewable energy throughout American Samoa. For example, there is only one experienced PV installer on-island. In addition, because renewable energy technology systems are relatively new to the island, inspectors may need training to be able to understand the necessary requirements for safe and successful system installation, ${ }^{17}$ and to ensure compliance with any new building and electrical codes. Developing local capacity not only ensures proper installation and operation of energy efficiency and renewable energy projects, and provides technical jobs for local residents.

The United States Department of Agriculture (USDA) Rural Development Office has found that there is a lack of information and knowledge about energy efficiency in the general public. Furthermore, according to the Land Grant Program, there are no sustainability or renewable energy classes offered onisland, making it difficult to develop expertise in energy efficiency or renewable energy. Providing citizens with this type of general knowledge about energy efficiency and renewable energy opportunities can develop market demand for clean energy technologies. Understanding the political and social structure is imperative to understanding how to develop and provide effective education programs. According to the USDA Resource Conservation and Development Office, the Office of Samoan Affairs has an excellent local network that could be used to implement education and outreach strategies.

\subsubsection{Building Codes}

The current building codes in American Samoa are outdated. They are based on the 1964 Edition Uniform Building Code, Volume 1, and have not been updated since the 1960s. The TEO is currently exploring options for adopting new building codes and is considering the impacts and feasibility of adopting the 2009 International Energy Conservation Code (IECC) Tropical Building Codes. Energyefficient building codes are critical in driving energy efficiency in the building sector and reducing future energy use in this sector. Enforcement of code compliance is integral in the effectiveness of any building code; training of inspectors will be an important piece of new building code implementation.

While the adoption of new building codes will address energy use in new construction and major renovations, energy use in the existing building infrastructure will remain an issue. Providing energy audits for residential and commercial customers is one way to assist customers in identifying costeffective energy efficiency improvements. Incentives for energy efficiency improvements can also be offered in conjunction with an audit program, further increasing the chances that efficiency improvements will be implemented.

\subsubsection{Net Metering Policy and Interconnection}

The net metering policy for distributed generation was added to the American Samoan Administrative Code, Title 12, Chapter 6, in 2008. ${ }^{18}$ The net metering policy allows for distributed generation systems up to $30 \mathrm{~kW}$ to participate in the net metering program based on ASPA's approval. Before interconnection will be allowed, the customer must provide ASPA with a certificate of completion indicating that the system has been properly installed and inspected and is in compliance with all building and/or electrical codes effective in American Samoa. The customer is responsible for installing appropriate safety equipment on the customer side of the meter including, but not limited to, an approved safety disconnect switch. If the customer's generation exceeds their monthly electricity use, the customer will be credited the excess to be used toward their next month's bill. A customer's generation will be reconciled annually on May 31 of each year, with excess generation forfeited. There is a one-time $\$ 45$ fee due to ASPA for interconnection and net metering.

\footnotetext{
${ }^{17}$ Jeff Shively, a project manager for the installation of ARRA solar projects hired a solar energy installation expert to train the inspectors on small-scale solar PV installations.

${ }^{18}$ www.dsireusa.org/documents/Incentives/AS01R.PDF.
} 
Currently, 22 customers have taken advantage of this policy and have interconnected PV with the grid; 10 government buildings, 10 commercial, 1 school and 1 residential totally $577 \mathrm{~kW}$.

\subsubsection{Territorial Government Electricity Use}

The central government pays ASPA directly for the electricity use of all American Samoan government agencies; agencies do not directly pay for their own electricity use. This creates a system where the government agencies are not keenly aware of the cost impact of their electricity use. Providing each agency with the funds to cover their electricity bills but requiring that they pay the bills directly can increase this understanding and alter electricity use habits. Furthermore, allowing each agency to keep all or a portion of the money they save by reducing electricity use would incentivize efficient use of electricity and result in additional funding for other agency work.

\subsection{Solid Waste}

Solid waste generation and disposal represent significant costs and challenges for island communities like American Samoa. Solid waste represents a potential source of material that can be converted to energy. The first step in determining the potential is to understand present waste management practices, waste generation quantities, waste composition, disposal costs, and regulatory environment.

American Samoa has engaged several consultants over the past 20 years to conduct assessments of waste management, including landfill expansions and recycling of imported metal products. ${ }^{19}$ In 1988 , SCS Engineers were engaged to review waste management practices. Based on this review, they made recommendations to improve operations, also recommending the implementation of a WTE facility with an electricity generation target of $\$ 0.16 / \mathrm{kWh}$ - with the potential of 50 tons of municipal solid waste (MSW) per day. Russell Mechem II conducted an assessment of solid waste management practices in 1995, which was funded by ASPA and the DOI office of Territorial International Affairs ${ }^{20}$. The Russel Mechem II report provided a reorganization of ASPA's solid waste program, and recommended the implementation of a two train - 50 to 60 tons per day (TPD) - WTE facility. Between 1996 and 1997 CalRecovery, Inc. ${ }^{21}$ (CALREC), an engineering consulting firm, conducted several studies for ASPA, focusing on the expansion of the existing landfill and the implementation of a WTE facility.

Additionally, CALREC assessed the capacity of recyclable materials and identified markets for the sale of the commodities. In 2008, the EPA also prepared an assessment of American Samoa, focusing on imported metal products. The assessment identified nearly 12 TPD of metals generated on the island. In 2009, SCS was again engaged to perform a detailed Waste Characterization and Waste-to-Energy Facility Study, which was completed September 16, 2009. ${ }^{22}$ All the assessments agreed that economically and socially, it is in American Samoa's best interest to develop a WTE facility and integrate a recycling program.

\subsubsection{American Samoa Waste Generation and Composition Analysis}

Solid waste collection in American Samoa averages 105,000 cubic yards per year, excluding fishery waste, waste oil, and tires. SCS Engineers performed a waste sort through two sampling periods, which included the dry season and the wet season ${ }^{23}$. The sampling estimated that the Futiga Landfill averaged between 76 and 110 TPD for solid waste, excluding waste oil and tires. Including waste oil and tires the average increased to 82 and 115 TPD.

American Samoa's waste stream can be segregated into three sectors:

\section{American Samoa Government}

\footnotetext{
${ }^{19}$ SCS Engineers. September 17, 2009. Waste Characterization and Waste-to-energy Facility Study. Pg 2-3 to 2-4.

${ }^{20}$ Ibid.

${ }^{21}$ CalRecover, Inc., www.calrecovery.com/landdisposal.htm.

${ }^{22}$ Ibid.

${ }^{23}$ SCS Engineers. September 17, 2009. Waste Characterization and Waste-to-energy Facility Study. Pg 2-3 to 2-4
} 


\section{Residential}

3. Commercial.

Additionally, further divisions can be identified between the different sectors of municipal solid waste:

- Solid waste

- Fishery biological waste

- Waste oil

- Tires.

Through SCS Engineers' waste sort, composition, and flow study they identified the annual averages for each sector, which are summarized in Appendix B: Waste Sort Data. Waste oil in American Samoa is currently collected and transferred to the local canneries for processing and recycling, which equates to 120,000 gallons/year or 510 tons. Additionally, tires from Goodyear, Ltd., and tires excavated from the tire landfill located at the ASPA scrap metal yard could generate an additional 20 tons of tires for WTE generation. SCS also estimated 66,000 tires per year (or one tire per person per year) are continually being generated on the island. This equates to 1,200 tons of tires per year available for use in a WTE facility. These resources additionally can be utilized by a WTE facility, minimizing the impacts to the environment while generating base load consistently priced electricity.

While performing the waste sort, SCS Engineers identified a total composition, and determined the most prevalent materials associated with overall waste stream. Figure 12 represents the waste composition analysis and materials identified in the waste sort. Appendix B: Waste Sort Data contains the most prevalent materials identified by the waste sort.

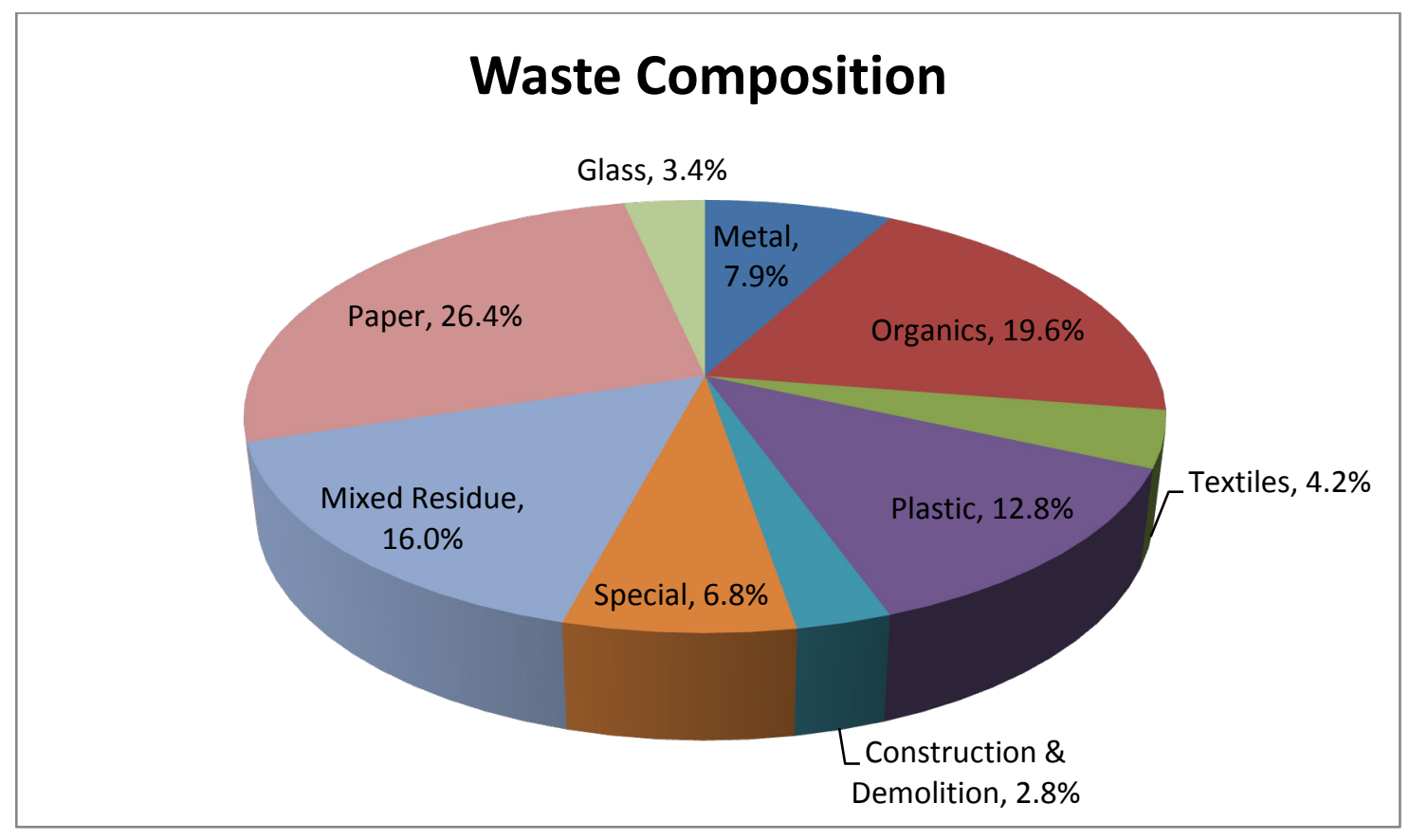

Figure 12. Waste composition developed by SCS engineers

Source: NREL

The overall heat value of the combination of constituents identified in the waste sort is much lower than expected, when compared to other MSW stream within the continental U.S. When only looking at MSW, the heating value is $2,873 \mathrm{Btu} /$ pound (lb). With the addition of the waste oil and tires, the 
heating value is raised to 4,058 Btu/lb. Appendix B: Waste Sort Data contains a summary of constituents and the heat value analysis of American Samoa's waste stream.

\subsection{Transportation}

All of the islands have a defined road system; personal transportation vehicles are available. Local bus service is available and highly utilized. Typically, SUVs or trucks are the primary mode of transportation. Due to the condition of many roads and topography, larger heavy-duty trucks, and SUVs are common as well.
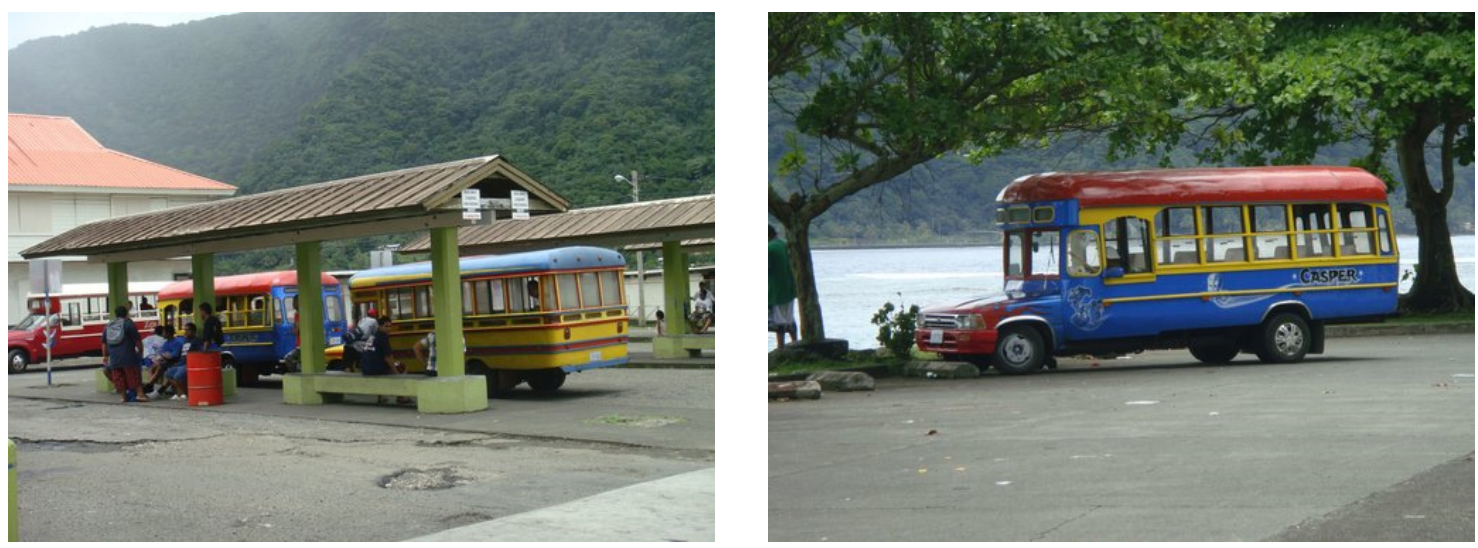

Figure 13. Transit buses in Pago Pago, American Samoa

Source: NREL/PIX 19418, 19419

Efforts to decrease fuel use in the transportation and other sectors could be undertaken, such as the implementation of high-efficiency personal vehicles and public transportation. A study of traffic patterns could be used as a starting point to inform an assessment of the need, costs, and fuel savings of any transportation strategy.

The implementation of alternate and electric vehicles is not likely a strong option until other utility-level means of generation are achieved, because almost all electricity is produced by diesel and the import cost of alternative fuels is typically high. In scenarios with high contribution of renewable energy sources, hybrid or standard electric vehicles would be more appropriate, especially to provide storage or stabilization to the grid using vehicle to grid technology. There are many additional benefits as well, including air quality improvements by producing less green house gas emissions and climate change mitigation.

As mentioned, NREL did not perform a transportation assessment and highly recommends this as a next step in order to see the full energy picture. 


\section{Energy Efficiency and Renewable Energy Opportunities}

As with many islands worldwide, American Samoa represents a high-priority location for the development of an integrated energy plan due to high energy costs, almost $100 \%$ dependence on imported fossil fuel, long distance to markets, and associated economic challenges. American Samoa currently meets nearly all of its electric power needs with diesel-fueled generation at a cost to consumers that may be unsustainable in the future.

This section of the report provides information on various opportunities as they relate to developing a strategic plan. Specific savings are difficult to quantify at this time due to the limited amount of data available during the site visit. Savings could be calculated based on energy audits from private industry and scaled-up across the sector, or more detailed audits could be conducted to determine specific savings. The opportunities presented in this section are based solely upon observations made during the site visit conducted by the NREL team while on-island.

\subsection{Energy Efficiency and Conservation}

There are many opportunities for energy and water efficiency and conservation in American Samoa. These opportunities include raising island energy and water consumption awareness in the various sectors, investigating alternatives to cooling, implementing a solar hot water program, conducting energy and water audits, improving aging infrastructure, and establishing metrics for improvement within the island building codes and equipment standards.

One energy efficiency program recently implemented was the installation of Feeder 10 from the Tafuna power station. The original set up had Feeder 9 containing a peak power demand of $4.7 \mathrm{MW}$ or $89 \%$ of its load capacity. ${ }^{24}$ This resulted in an annual distribution loss of 5.1 MWh. By installing Feeder 10, the distribution losses are decreased to $1.6 \mathrm{MWh}$, or a $69 \%$ reduction in distribution loss. Feeder 10 picks up 2.2 MW of maximum demand, leaving Feeder 9 to carry $2.5 \mathrm{MW}$.

\subsubsection{Building Stock}

Buildings are an energy challenge because they account for most energy consumption. Globally, buildings are responsible for $49 \%$ of global energy consumption and $47 \%$ of greenhouse gas emissions. ${ }^{25}$ However, buildings also provide the best opportunity to reduce both consumption and emissions. Taking inventory of building stock is very important. Energy use will vary by construction type and materials, age, and function of the building, and type of equipment in use. Other parameters that impact energy use are climate, culture, and the ability to operate and maintain equipment properly. The key to reducing energy consumption is to understand how energy is being utilized and to know where conservation and efficiency measures can be effectively applied. By identifying the end-uses of energy, analysis can be undertaken to identify areas where the most impactful and cost-effective improvements can be made. Some of these improvements may be low or no cost, such as operational changes or education, while others may require a larger investment, such as cooling system upgrades.

In American Samoa, the building portfolio consists of residential, commercial, canneries, hotels, schools, hospital and governmental structures. According to the TEO State Energy Program (SEP) Plan, the majority of dwellings are detached single-story units built with cinder concrete blocks. This type of construction is inexpensive and withstands wind and water resulting from potential typhoons and storms.

Some older wood structures that were built before 1990 remain in place on American Samoa. Buildings that are lightweight and constructed of wood frames or are older with deteriorating structures are vulnerable to damage or destruction; major destruction was incurred from the 2009 earthquake and

\footnotetext{
${ }^{24}$ Benefits of a New Distribution $13.2 \mathrm{kV}$ feeder F10 - Tafuna Power Plant.

${ }^{25}$ www.nrel.gov/docs/fy10osti/48318.pdf.
} 
tsunami on several of these structures. The highest buildings are three stories and include the Government Executive Office, the Centennial Bldg and Tradewinds Hotel. There are 10,052 residential units and 1,282 government and commercial structures in American Samoa. ${ }^{26}$ Table 5 summarizes the building types in American Samoa.

Table 5. Building Types ${ }^{27}$

\begin{tabular}{|c|c|c|c|}
\hline & Wood & $\begin{array}{c}\text { Cinder Blocks with } \\
\text { Metal Roofing }\end{array}$ & Metal \\
\hline Government & $25 \%$ & $75 \%$ & 6 bldgs \\
\hline Commercial & $2 \%$ & $30 \%$ & $68 \%$ \\
\hline New Residential (44\%) & - & $100 \%$ & - \\
\hline Old Residential (56\%) & $50 \%$ & $50 \%$ & - \\
\hline
\end{tabular}

164 building codes imply all buildings are inefficient; American Samoa can address which energyefficient building retrofit technologies can produce the greatest cost savings. Collecting end-use data is important as it enables study into the highest potential of savings per capital cost investment with technologies, such as more energy-efficient air conditioners, lighting, appliances, and glazing or tinting of windows. Energy costs are becoming a major consideration to many home owners. Statistics show that in many island communities a greater percentage of a household's overall budget is spent on energy than in mainland communities where the cost of energy is much less. Whether small or large, costeffective building retrofits are an opportunity in American Samoa for increased energy efficiency and advanced energy management.

EPA's Portfolio Manager can be a useful tool for managing building stock and benchmarking energy use across a portfolio of buildings. Once energy and water use information has been assembled, the tool allows consolidation of data into a Web-based database to track energy consumption, performance, and cost information. This may be useful for benchmarking and tracking performance of American Samoa's portfolio. The Portfolio Manager tool and more information can be found on the EPA website. ${ }^{28}$

The American Samoa EPA has begun deconstruction and construction of their new headquarters using green and sustainable materials and practices is five primary categories such as transportation accessibility, water efficiency, material recycling and reuse, energy use and innovation. Special features will include; PV power generation, solar orientation, double insulated wall system, insulated glazing and solar shades, and a green roof.

\subsubsection{Review and Improve Energy Efficiency Standards to Improve Efficiency}

As mentioned in the policy section, the current building codes in American Samoa are outdated; they have not been updated since the 1960s. The adoption of new building codes could address energy use in new construction and major renovations, effectively increasing the efficiency of these buildings.

However, the existing building infrastructure will remain an issue.

Tropical building codes, like those adopted in Hawaii and now being considered by American Samoa, would increase the efficiency of new buildings as well as those undergoing major renovations. The building industry will need time to learn building codes and train personnel to meet these codes, so integrating energy efficiency as early as possible will assist with faster implementation of energy efficiency measures in new construction. Equipment standards should also be reviewed to eliminate/reduce energy intensive equipment that is available to consumers, such as incandescent light

\footnotetext{
${ }^{26}$ American Samoa State Energy Program Plan Summary, 2009.

${ }^{27}$ Ibid.

${ }^{28}$ www.energystar.gov/index.cfm?c=evaluate_performance.bus_portfoliomanager.
} 
bulbs and non- ENERGY STAR ${ }^{\circledR}$ or EcoLabel appliances. The European EcoLabel scheme is comparable to the ENERGY STAR rating system in the United States, and these products are good models to follow for recommending equipment that meets specific criteria for meeting energy reduction goals in American Samoa.

\subsubsection{Outreach}

Outreach strategies are very important when trying to illicit change, especially in the energy sector. In order to begin an awareness campaign an audience would need to be identified, materials prepared, and launch dates selected. Campaigns should be ongoing and will need to be reviewed and revised every few months to communicate specific messages to target audiences. Outreach activities within a community may include inserting articles in newsletters or a weekly newspaper insert, posters and flyers, stickers for light switches and equipment, fun and educational events for children and adults, and informational inserts in electric bills. A different campaign could be created for each specific audience. For example, water reduction strategies should also be included in education and outreach campaigns, starting with the various building sector types. An energy and water awareness campaign is a low-cost solution for encouraging energy and water conservation.

Also, stakeholders in the building construction and remodel industry can be educated in energy and water efficiency. Architecture and engineering (A\&E) firms, as well as those in the construction industry, should have a targeted outreach program regarding climate-specific design and energy-efficient and water saving technologies.

Some efforts that may result in both behavioral and technical improvement are summarized by the section below.

\section{Residential}

- Education campaigns for local communities focused on energy awareness and conservation strategies.

\section{Commercial}

- Work with various sectors to increase awareness through posters, stickers, fact-sheets, etc.; this should include conservation strategies, efficient technologies, and proper operation and maintenance

○ Work with island suppliers and retailers to source energy efficient technologies.

\section{Construction industry}

- Provide information and training on building codes, design practices, and energy efficiency measures that should be incorporated into new construction and renovations, such as external shading for windows, coating coastal air conditioning unit coils to protect from sea mist, proper insulation techniques, high seasonal energy-efficiency ratio air conditioning units, etc.

\subsubsection{Create an Energy and Water Audit Program}

Energy audits of government facilities have been funded under the Recovery Act, and are expected to begin following the training of local audit providers. Results from this effort should be used to prioritize investment in energy-efficient strategies and technologies that can be implemented immediately. It is also recommended that building audit results be applied to developing a strategy where conservation measures are relevant to multiple buildings within a specific sector. For example, audit results of a representative sample of typical office buildings should be applied to similar structures. It is also recommended that local private companies or trades people be trained to perform the audits, as those services would then be available to the community at-large, benefitting the local economy. 
It is recommended that a comprehensive building audit program be developed for commercial and government buildings as well as residential houses.

\subsubsection{Cool-Roof Technology}

The U.S. Department of Energy's (DOE) Secretary Steven Chu launched a series of initiatives in July 2010 to encourage cool-roof technologies in the federal government. Secretary Chu has directed all DOE offices to install cool roofs (whenever cost effective over the lifetime of the roof) when constructing new or replacing old roofs, and in areas where cool roofs will be beneficial to energy efficiency savings (typically in hot climates). While these initiatives are targeted at federal buildings, the cool roof program has materials and resources that would be beneficial to American Samoa. Cool roofs are roofs designed to maintain a lower roof temperature than traditional roofs while the sun is shining, typically through reflectance technologies. Not all cool roofs need to be white, as indicated in Figure $14 .^{29} \mathrm{~A}$ cool roof program could be implemented island-wide by using low-cost technologies, such as elastomeric paint ( $\sim 40 /$ gallon), which would need to be applied to roofs and maintained through a cleaning program to prevent debris and mold build-up. More information about selecting buildings and implementing a cool roof program can be found on the DOE website. ${ }^{30}$

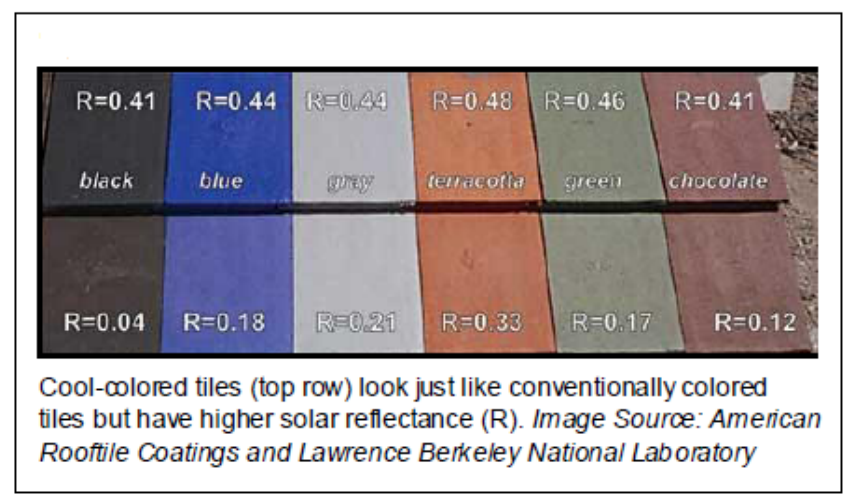

Figure 14. Cool roof tiles in colors other than white Source: DOE

\subsubsection{Energy Efficiency and Conservation Next Steps}

The following five steps are recommended:

1. Conduct a review of the existing building codes and equipment specification standards. The end goal of a building code and specification analysis would be to highlight areas where improvements could be made and where American Samoa could benefit by changing the building code and standards. Other islands or island nations, such as the state of Hawaii, with energy efficiency standards already incorporated into codes and standards could be used as a model.

2. Create energy and water audits program and apply measures where they are more broadly applicable. A strategy for identifying and implementing the measures that are most commonly identified in the energy audits could be a next step, but would require disclosure from the entities conducting the energy and water audits.

3. Evaluate whether a cool roof program is appropriate.

4. Begin an energy and water awareness campaign within the various building sector types. An energy and water awareness campaign is a low-cost solution for implementing energy and water conservation. Pilot projects could be carried out within specific buildings or

\footnotetext{
${ }^{29}$ DOE. Guidelines for Selecting Cool Roofs. July 2010. www1.eere.energy.gov/femp/pdfs/coolroofguide.pdf.

${ }^{30}$ wwwl.eere.energy.gov/femp/features/cool_roof_resources.html.
} 
communities to highlight the impact of the campaign on consumption. In order to begin an awareness campaign the audience would need to be identified; materials prepared, and launch dates selected. Campaigns should be ongoing and would need to be reviewed and revised every few months to communicate specific messages to target audiences. Outreach activities within a community may include inserting articles in newsletters or a weekly newspaper insert, posters and flyers, stickers for light switches and equipment, fun and educational events for children and adults and informational inserts in electric bills. A different campaign should be created for each specific audience and may include the following:

1. Government employees

2. Hotel staff and guests

3. Medical staff

4. Education staff, teachers, and students

5. Community residents (adults and children).

5. Create training materials for A\&E firms as well as the construction industry to increase knowledge relating to energy-efficient technologies and practices. Training materials could take the form of curriculum for workshops, handbooks, presentations, websites, and other tools. A training module would need to begin with an assessment of the current level of knowledge and indicate areas of the greatest need for improvement. The audience would need to be assessed so that materials could be tailored to be the most effective.

\subsection{Renewable Energy}

Although energy efficiency will play a critical role in addressing energy consumption and costs across American Samoa, the costs for diesel-derived commercial and residential power generation will remain a drain on the American Samoan economy. The incorporation of renewable energy technologies, initially at lower levels, but increasing in overall contribution over time, is a critical part of reducing the amount of fuel imported for power generation. Additionally, as seen in other isolated communities, with lower cost or cleaner electrical power it may become possible to convert some of the transportation sector to electric technologies, further reducing the impacts of fossil fuel imports.

There are many renewable energy opportunities for American Samoa, although more detailed project and resource assessments are needed to confirm the viability of specific options for development. Most notably and discussed at greater length are wind, solar, and biomass technologies. Additional technologies, such as ocean thermal, tidal, and wave power could also be considered but are not currently viable technologies from a cost or technology readiness perspective, and thus are not included in this document. Each of the major renewable power options for American Samoa, as well as additional information and analysis needed for development, are discussed in the following sections.

\subsubsection{Wind}

Wind energy has the potential to play a significant role in supplying electrical energy to American Samoa. Combining the available wind resource, with a high level of existing infrastructure, and high energy costs; make wind technology an attractive potential addition to the current generation portfolio. Currently, the Territorial Energy Office received a grant through the Recovery Act for the installation of several anemometers. ASPA is managing this project and is in the process of installing anemometers at various heights on existing power poles and communication towers and provided Figure 15. 


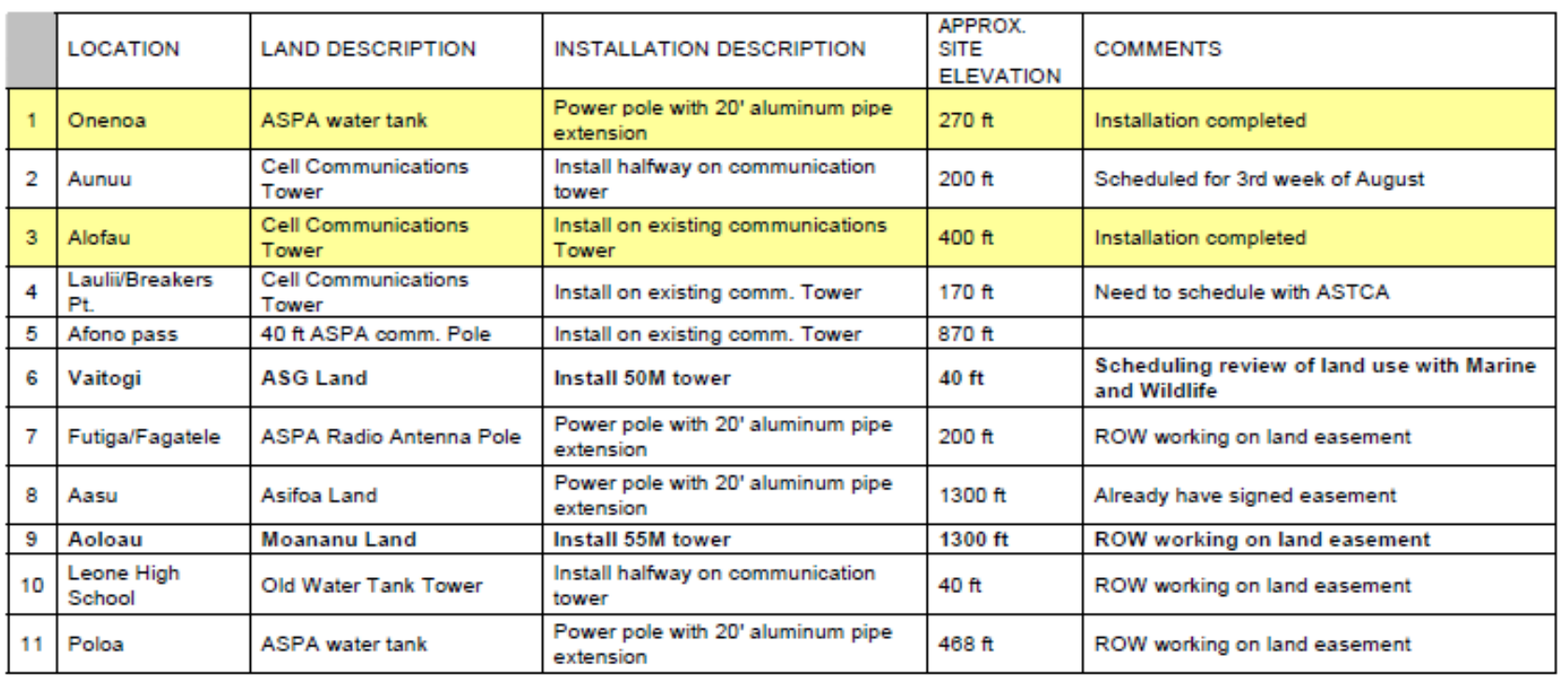

*Site elevation does not include height of Anemometers - these will be measured after installation

Figure 15. Anemometer study details ${ }^{31}$

Several sites have been identified as depicted on the following Figure 16 and Figure 17:

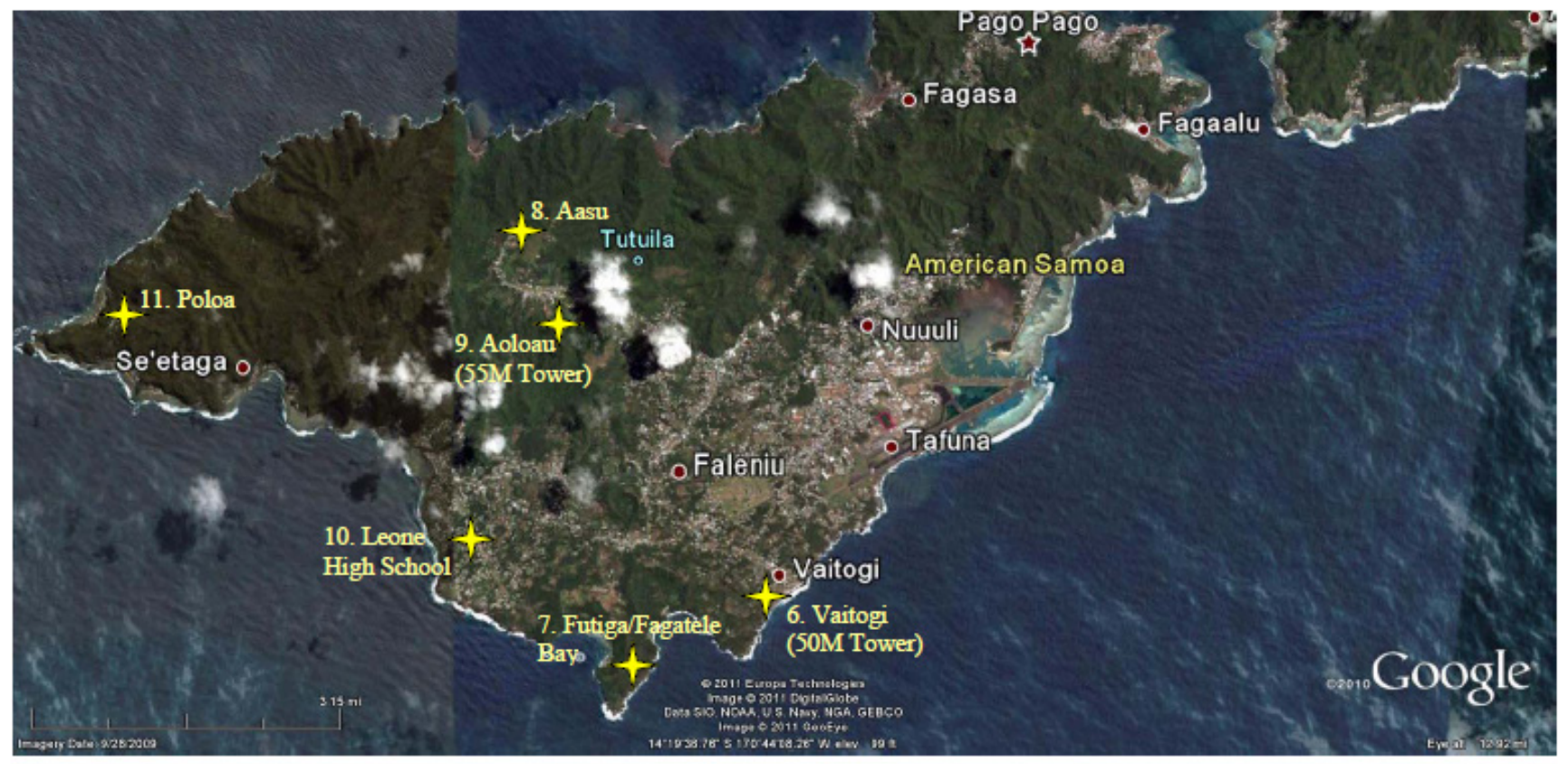

Figure 16. West side sites ${ }^{32}$

${ }^{31}$ Provided by ASPA project manager.

${ }^{32}$ Ibid. 


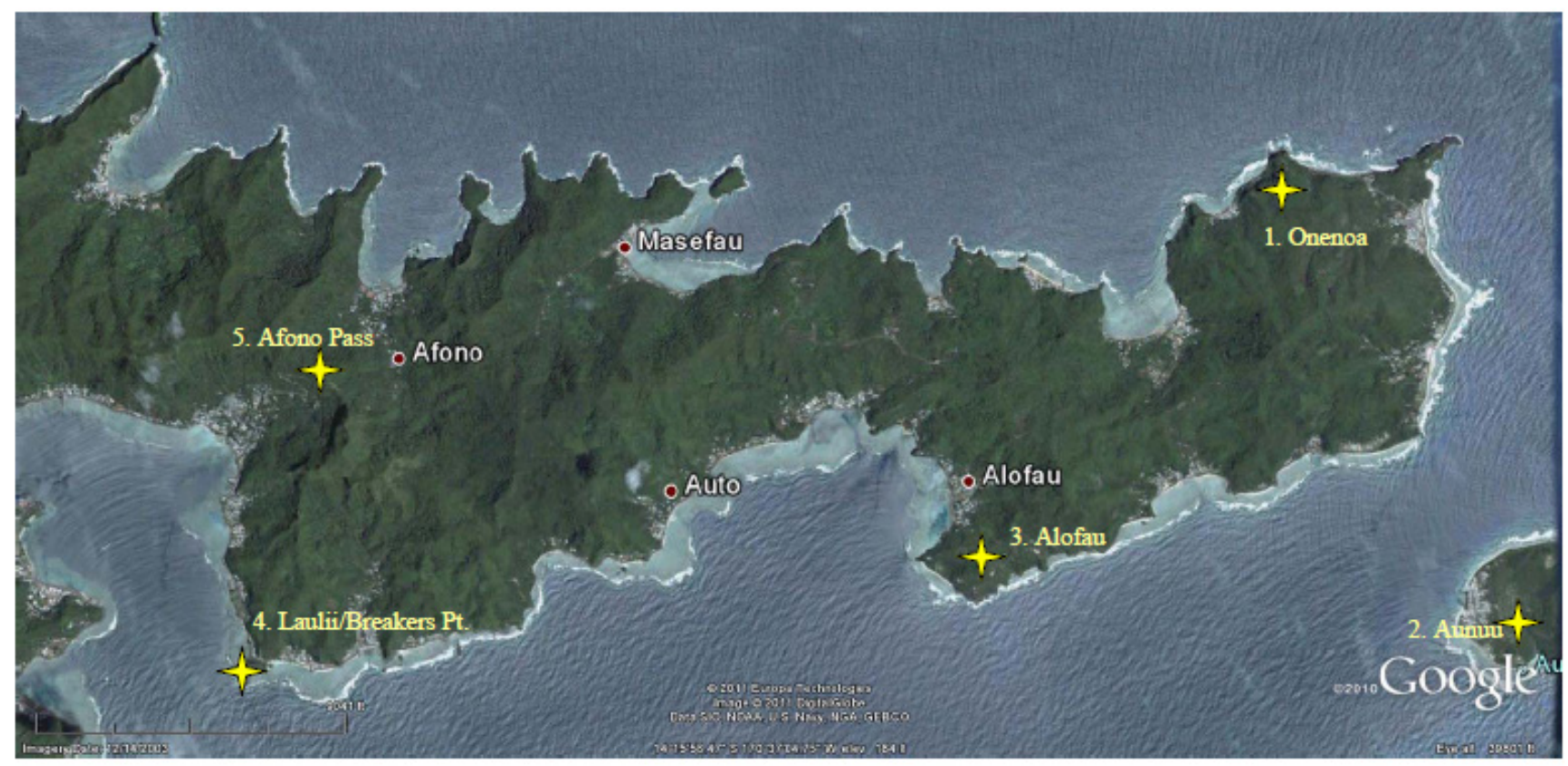

Figure 17. East side sites $^{33}$

\subsubsection{Key Challenges to Wind Development}

There are several key elements that need to be taken into account when considering the deployment of wind technologies. In the context of American Samoa, environmental impact, grid impact, and social acceptance must be carefully pondered when proposing wind deployment on the island.

To date, there has been no significant wind energy installation on the island and thus the potential environmental impact for new wind installations are poorly understood. Gaining a firmer understanding of and the ability to communicate the potential impacts for prospective wind projects will be of great importance especially when considering the fragility of the island's small ecosystem.

Because of the variable nature of wind energy and the relatively small grid, maintenance of grid stability will need to be a principal focus. Fortunately there is considerable prior experience in both island and other small grids, even at similar grid sizes, and successful integration of wind is well beyond the demonstration stage. Furthermore, due to the high cost of conventional power generation, supplemental integration equipment can readily be included into the wind project budget while maintaining strong economic viability.

Social acceptance of wind technology, especially when a wind installation is among the first on the island, is a concern and thus public outreach for the project must be carefully managed early on in the project scoping and evaluation process. Due to the small size of American Samoa and generally high population density on the coast, any coastal development site will result in a social impact. This impact can be in the form of sound and visual clutter, although flicker (the strobe effect of shadow caused by the wind turbine blades) could also be brought up as concern. Project acceptance is greatly improved when the local community understands and appreciates the clear community benefits of the project. The fact that a wind project provides a means to control and reduce the cost of energy to all utility customers enhances the likelihood of public acceptance of the project; management of this message is critical for eventual project success. 


\subsubsection{Wind Infrastructure}

The infrastructure for the development of small-scale wind deployment on American Samoa, although challenging, is not seen as a critical issue. The only current limiting factor is the availability of a heavy lift crane to support turbine installation. It is unlikely that a suitable crane is available on-island and instead will have to be shipped to the island. This issue will be reflected in the project economics but will not impact the technical viability of the project.

Typhoons do pose a risk in the use of wind technologies. All larger wind turbines are designed to stop operating in high wind conditions, meaning that in all except the most extreme cases storm-related damage is going to focus on that caused by airborne debris, typically to the turbine blades. The other potential issue would be the wind loading on the turbine structure exceeding the tower or foundation design loads, which are controllable factors, although they can cause increased implementation costs representing an engineering design issue. Although there has not been much experience with large turbines in the Pacific, a number of turbine installations in the Caribbean have not reported major issues, including a small system of four turbines installed at Guantanamo Bay on the eastern end of Cuba, an area with common hurricane (typhoon) activity.

Looking at the implementation of turbines installed in areas with known typhoon or extreme weather events, consideration must be given to both turbine selection and an assessment of the risk for the turbine structure, which may lead to the purchase of insurance. Every large wind turbine is designed around an international standard for wind intensity, provided in a class rating. The class rating will also impact the size of the wind turbine rotor, which will have an impact on the resulting energy generation from the turbine.

Currently, two manufacturers have a typhoon-rated wind turbine. Additionally, several wind turbine manufactures make turbines that are designed to be lowered during potential typhoon events, such as the Vergnet $220 \mathrm{~kW}$ turbine. Other companies are testing a larger turbine where the rotor of the turbine is removed. In all cases however, the purchase of insurance, or in cases of self-insured companies, an assessment of risk, is used to assess the appropriateness of installing wind in any environment.

Historically, insurance companies have not been willing to provide insurance for turbines in Class V typhoon areas, such as American Samoa. In any case, one of the first steps in the development of potential projects will be to contact wind turbine manufactures, either informally or through a competitive process, to better determine what products are available; survival wind speed, as well as typhoon experience, should clearly be one of the key competitive requirements.

\subsubsection{Wind Next Steps}

The following next steps are recommended:

1) Finish the preliminary wind development assessment for American Samoa. With the expectation that the development of any wind site will be conducted through a competitive request for tender, the more information that is available about the site will result in improved project design and economics. This activity would lay the groundwork for site development by conducting all of the required initial screening studies. Other elements of the feasibility study would include:

- Resource assessment combined with data correlation to be synthesized from the installed towers after one year. In addition, new remote sensing techniques are quickly becoming available, which may significantly shorten the required monitoring time when appropriately correlated to nearby long-term datasets.

○ Land title assessments 
- Identification of candidate wind project development zones including site access and mobilization suitability

- Develop clear and balanced wind rules, regulations, permitting requirements that establish a clear wind development process

- Initial environmental impact assessments

○ Geotechnical assessments

○ Construction and erection equipment survey to establish availability for suitable onisland equipment

○ Initial grid interconnection and impact assessments.

2) Initiate an active social acceptance outreach and education activity about wind. For successful project development it will be critical to get ahead of the information around the deployment of wind technologies on American Samoa. This would include the quantifying of potential positive impacts, such as job creation, economic development, and consumer savings while simultaneously collecting and developing information regarding potential negative impacts, such as conducting a noise impact assessment and visual simulations. All of this information should be publically available with open forum discussions conducted by ASPA and another appropriate organization to identify and address potential issues. If at all possible this should be implemented during the initial assessment phase (within the next year) to get ahead of any development of inaccurate preconceived notions. This activity and the information generated through it should not directly advocate for a wind project, but should provide fair and balanced information on the various impacts of wind development.

3) Feasibility and economic assessment of the project. Additionally, the met tower should be considered a temporary structure and should not be subjected to typhoon building codes.

\subsubsection{Solar}

There are great opportunities for using solar technologies in America Samoa. Solar renewable energy technologies are often broken down by solar thermal and solar electric (PV) applications. Solar thermal technologies capture energy from the sun to heat water, also known as solar hot water; they can also be used to heat air for direct use or to make steam for electrical production. PV technologies use the photons from the sun to create electricity. These two technologies and their applications are outlined in this section; solar radiation data can be found in Appendix C: Solar Radiation Data.

\subsubsection{Solar Thermal}

Solar thermal technologies can be used to heat water for direct use in buildings or in applications, such as pools, or they can be used to generate steam to produce electricity.

In American Samoa there are some sectors that heat water and rely on electricity. Domestic solar thermal hot water technologies use the sun to heat a fluid, usually water in non-freezing climates. The water is then used in domestic applications such as showers, pools, or washing machines. These systems are typically low- to medium-cost and easy to install. Solar hot water should especially be considered within the larger industries where hot water consumption is high, such as hotels, restaurants, Laundromats, and hospitals. By reducing the amount of hot water being generated through conventional forms of heating, the demands on fossil fuels can be lessened. 


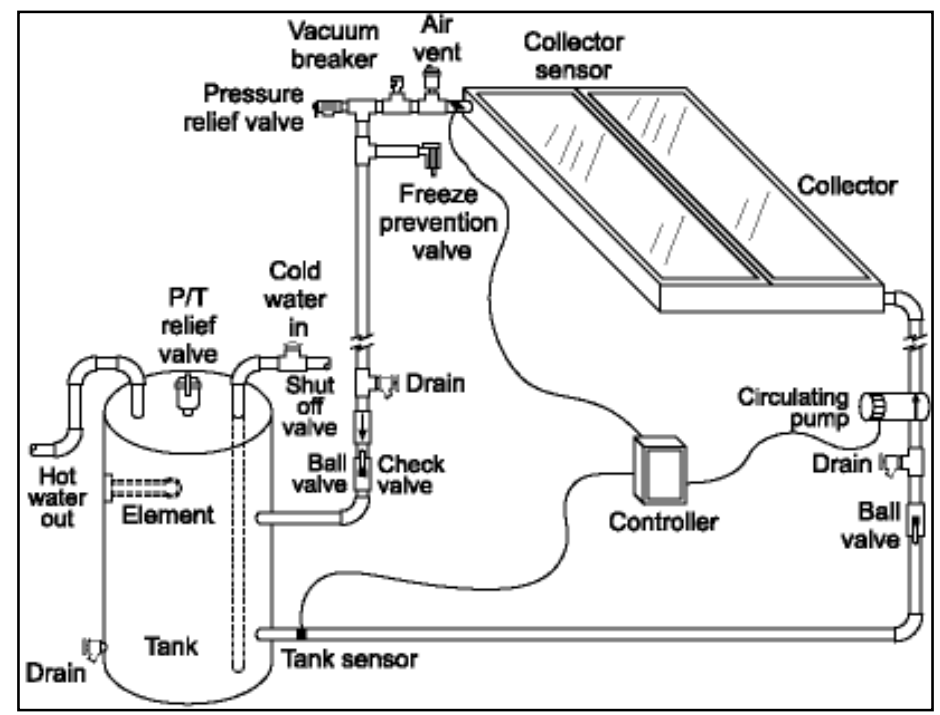

Figure 18. A common solar thermal system

Source: NREL

Figure 18 shows a common solar thermal system used for hot water heating. ${ }^{34}$ A solar collector captures the heat from the sun and then gravity typically draws a fluid out of the collector to act as a heat exchanger to transfer the heat to another material, such as water in a tank. Pressure relief valves and circulation pumps are needed to maintain pressure and keep the fluid moving through the distribution system. Panels should be installed where there is exposure to the sun without shading from buildings or vegetation. They should also be installed in locations where they will not be vandalized or tampered with, and they should be installed according to updated building regulations, plumbing, and access codes. $^{35}$

Through a Department of Energy TEO ARRA grant the Lyndon B. Johnson Tropical Medical Clinic on Tutuila is currently installing solar thermal units that will heat approximately 3,000 gallons of water per day.

\subsubsection{Solar PV}

PV arrays convert sunlight to electricity without moving parts and without producing fuel wastes, air pollution, or greenhouse gases. They require very little maintenance and make no noise. Arrays can be mounted on all types of buildings and structures. PV direct current output can be conditioned into gridquality alternating current electricity or used to charge batteries.

Traditional "single crystal" solar cells are made from silicon, are usually flat-plate, and are generally the most efficient. "Multi-crystal" are a similar technology but slightly less efficient. A third type are called "thin-film" solar cells because they are made from amorphous silicon or non-silicon materials such as cadmium telluride. Thin film solar cells use layers of semiconductor materials only a few micrometers thick. See Table 6 for an overview of module efficiencies.

Table 6. Typical Efficiency of Different Types of PV cells

\begin{tabular}{||l|l|l||}
\hline \multirow{2}{*}{$\begin{array}{l}\text { Module } \\
\text { Efficiencies }\end{array}$} & Single Crystal & $14 \%-19 \%$ \\
\cline { 2 - 3 } & Multi-crystal & $13 \%-17 \%$ \\
\cline { 2 - 3 } & Thin Film & $6 \%-11 \%$ \\
\hline
\end{tabular}

\footnotetext{
${ }^{34}$ www.nrel.gov/docs/gen/fy04/36831m.pdf.

${ }^{35}$ www.nrel.gov/docs/fy99osti/26579.pdf.
} 
Because of their flexibility, thin film solar cells can double as rooftop shingles and tiles, building facades, or the glazing for skylights. ${ }^{36}$ Figure 19 shows an example of this technology integrated into shingles. Examples of building integrated PV include shingles, singly ply membrane, standing seam metal roofs, and others.

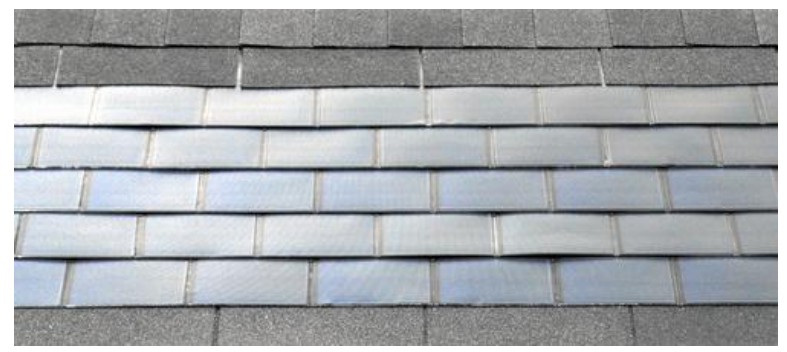

Figure 19. Thin film solar PV shingles

Source: NREL

Most systems installed today are in flat-plate configurations typically made from solar cells combined into modules that hold about 40 cells. A typical home in the mainland will use about 10 to 20 solar panels to power the home, but for American Samoa, residential use is much less and will require smaller systems. It is important to note here that all solar systems be properly sized taking into account size and scale, need and desired outcome. For large electric utility or industrial applications, hundreds of solar arrays are interconnected to form a large utility-scale PV system. ${ }^{37}$ These systems are generally fixed in a single position, but can be mounted on structures that tilt toward the sun on a seasonal basis or on structures that roll east to west over the course of a day. ${ }^{38}$ Figure 20 below shows the components of a typical residential-size PV system.

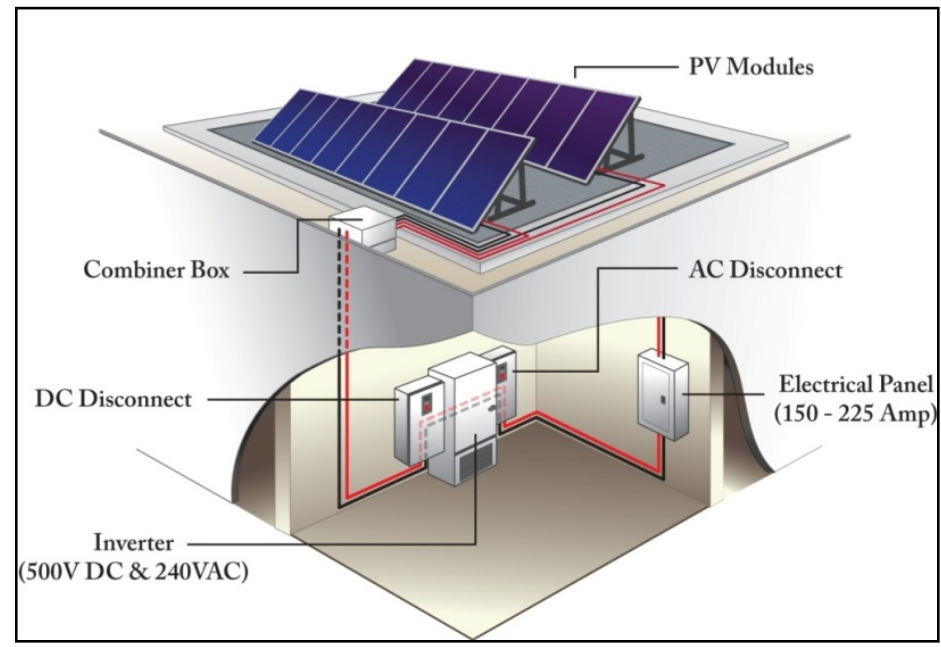

Figure 20. PV system schematic

Source: NREL

The cost of PV-generated electricity has dropped 15- to 20-fold in the last 40 years; in 2010 gridconnected PV systems sold within the range of about $\$ 4 / \mathrm{Watt}$ peak (Wp) to $\$ 7 / \mathrm{Wp}(\$ 0.16 / \mathrm{kWh}$ to $\$ 0.28 / \mathrm{kWh})^{39}$, including support structures and power conditioning equipment. Watt peak is the power

\footnotetext{
${ }^{36}$ www.nrel.gov/learning/re photovoltaics.html.

${ }^{37}$ www.nrel.gov/learning/re_photovoltaics.html.

${ }^{38}$ DOD RE Replication Pilot ESPC.

${ }^{39}$ U.S. Solar Market Insight - 2010 Year in Review Executive Summary. Solar Energy Industries Association. 2010 SEIA/GTM Research.
} 
rating that a PV system measures under standard test conditions, and under which a panel could be expected to deliver its peak output. An NREL study of 7,074 PV systems installed in 2007 reported a range of total capital cost averaging $\$ 8.32 / \mathrm{Wp}$ for small systems less than $10 \mathrm{~kW}$ and $\$ 6.87 / \mathrm{Wp}$ for large systems greater than $100 \mathrm{~kW}$. Costs reported for PV projects are changing rapidly (i.e. getting lower) so a local solar installer may be the best source of cost information. Operation and maintenance costs are reported at $\$ 0.008 / \mathrm{kWh}$ produced, or at $0.17 \%$ of capital cost without tracking and $0.35 \%$ with tracking. ${ }^{40}$ They are very reliable and last at least 20 years or longer. As with all insular communities such as American Samoa however, shipping costs are a factor and can increase costs from the mainland by $20-25 \%$. Costs can be kept down by ordering in bulk and sharing with other neighboring islands or purchasing internationally as appropriate. However, many federal grants are subject to the Buy American Act .

The amount of electricity that a system produces depends on its type, orientation, and the available solar resource. The solar resource is the amount of the sun's energy reaching the earth's surface, which varies at different locations around the world. A higher solar resource means that more of the sun's energy is reaching the surface, which is optimal for PV system performance. PV systems can use both direct and diffused solar radiation. The solar resource in American Samoa is quite good, averaging 5.42

$\mathrm{kWh} / \mathrm{m}^{2} /$ day (based on modeled resource data). The solar resource data is found in Appendix C: Solar Radiation Data.

\subsubsection{PV Opportunities}

ASPA has signed a contract with Sun Wise, a company out of California who won the bid to install a 1.5 MW of PV, as mentioned in Section 2.2.3. Although the utility has minimal experience with large-scale PV projects, they have been sending staff to trainings and working to build in-house capacity for this technology. PV may be an opportunity for electrical production in American Samoa, and the utility may want to consider additional, large-scale PV systems as well as encouraging small, distributed PV systems on residential and commercial properties.

PV is particularly well-suited and cost-effective in locations that are not grid-tied, or are grid-tied but suffer frequent and continuous outages. The National Park Service (NPS) Ofu Ranger Station and Marine Research Station may be good locations for the installation of a PV system, or multiple systems. It was stated that these sites are at the end of the electrical distribution system and frequently experience outages. Also, NPS is actively pursuing clean energy and energy efficiency technologies, and this would be an appropriate site to promote solar PV. ${ }^{41}$

\subsubsection{Solar Next Steps}

The following next steps are recommended:

1) Conduct a feasibility study to analyze the potential for increased deployment of both largeand small-scale PV installations in American Samoa. This can aid in utility planning for new infrastructure including controls, storage, and dispatchable power sources.

2) Consider creating incentives or other policies for supporting the installation of solar hot water heaters, particularly in high hot water use applications such as hotels, Laundromats, restaurants, and cannery operations.

3) Measure or procure direct normal insolation solar resource data on American Samoa, which can then be used to conduct an analysis of the potential for concentrating solar power if appropriate.

\footnotetext{
${ }^{40}$ Mortensen, J. Factors Associated with Photovoltaic System Costs. NREL/TP 620.29649. June 2001; p. 3.

${ }^{41} \mathrm{http}$ ://pacificislandparks.com/2011/01/31/national-park-promotes-climate-change-research-and-awareness/.
} 
4) Conduct an analysis of the potential for PV to offset some or the entire electrical load at the NPS Ofu Ranger Station and Marine Research Station.

5) Evaluate the performance of the recently installed PV systems to compare actual generation versus expected generation.

6) Conduct performance measures from the 1.5-MW solar project at the airport. Evaluate the success and lessons learned from this project

\subsubsection{Biomass}

Biomass is generally defined as any organic feedstock available on a renewable basis. Typical biomass resources include wood and wood waste, MSW, landfill gas, agricultural and crop residues, human solid waste, animal manures, and biogenic waste. One of the primary benefits of biomass is that feedstocks can be stored, thus allowing for baseload, dispatchable generation. If using a biofuel, such as biodiesel, the fuel can be used directly in existing equipment, thus allowing for renewable fuel switching at minimal capital cost.

Biomass resources that are potentially suitable for American Samoa include:

- Generation of electricity from MSW

- Production and use of biodiesel in existing diesel power plants

- Capturing landfill gas for energy recovery

- Generating biogas at waste water treatment plants through anaerobic digestion

- Generating biogas at fishery processing plants through anaerobic digestion

- Production of dedicated feedstocks to produce solid or liquid biofuels

During the site visit, the NREL team evaluated potential opportunities to develop each of these options.

\subsubsection{Waste-to-Energy}

SCS Engineers identified multiple options for a WTE project approach ${ }^{42}$. These options include a traditional A\&E approach, where an engineering company would develop the design, technical specification, and calculations, and would then deliver those to ASPA in multiple packages. The packages would then be procured by ASPA, including equipment and construction. The second approach would be utilizing an Engineering, Procurement, and Construction contractor, to provide a design, perform all procurement and construction activities, start-up and commission the facility, then turn it over upon acceptance by ASPA. This would leave ASPA the responsibility to operate the facility or to hire a contractor to operate. The final option would be to implement a full service approach, where through mechanisms of guaranteed payments for electricity and MSW disposal, the contractor would design, bid, build, and operate the facility. The contractor would then retain ownership of the facility, while ASPA would benefit from the power generation and the waste management and minimization of products landing in a landfill.

American Samoa will need to perform a substantial risk assessment, while conceptualizing the installation of a WTE facility on the island. Even though some of the risk associated with owning and operating a WTE facility was completed by SCS Engineers, risk in the areas of energy and materials market, legal and regulatory, facility construction, and facility operation need to be monitored and addressed as the project develops and continues to operate.

\footnotetext{
${ }^{42}$ SCS Engineers. September 17, 2009. Waste Characterization and Waste-to-energy Facility Study. Pg 2-3 to 2-4
} 
The generation and disposal of MSW presents challenges for most communities, but especially islands. Converting MSW to energy is one option that many communities have either undertaken or are considering.

SCS's best estimate is that American Samoa produces approximately 82 to 115 TPD of MSW on a 6day basis, which is deemed to be potential feedstock for a WTE facility. The 82 to 115 TPD of MSW based on 6 days of collection, was used to determine an annual collection range of 25,666 to 35,995 TPY of MSW. When taking into account the facility would have an expected capacity factor of $85 \%$ of a WTE facility, this equates to 83 to 116 TPD of MSW. According to the SCS Engineers' report, this feed rate includes household waste, government waste, commercial waste, waste oil, and tires. There may be other feedstocks available, such as sludge from wastewater treatment plants, green waste, and some small quantities of agricultural residues. As these resources have not been quantified (and to do so is beyond the scope of this report), they are not included in the following analysis.

As shown in Table 7, the estimated amount of MSW would be sufficient to supply a 1.6-MW to 3.14MW (net output) plant with an $85 \%$ capacity factor. The actual generation will be highly dependent on the selected technology, the overall composition of the feedstock, how the feedstock is handled and prepared (e.g. is it processed into refuse derived fuel or used as is?), system design, and overall operating conditions.

Table 7. Summary of Waste-to-Energy Potential

\begin{tabular}{|l|r|r|r|r|r|}
\hline \multirow{2}{*}{ Input } & \multirow{2}{*}{ Units } & \multicolumn{2}{c|}{ High Efficiency } & \multicolumn{2}{c|}{ Low Efficiency } \\
\cline { 3 - 6 } & & High Waste & \multicolumn{1}{c|}{ Low Waste } & High Waste & \multicolumn{1}{c|}{ Low Waste } \\
\hline Feed w/6 day opp) & TPD & 115 & 82 & 115 & 82 \\
\hline Feed Rate w/CF & TPD & 116 & 83 & 116 & 83 \\
\hline Heat Input & Btu/lb & 4,058 & 4,058 & 4,058 & 4,058 \\
\hline Day Heat & Btu/day & $941,612,957$ & $671,410,978$ & $941,612,957$ & $671,410,978$ \\
\hline Hour Heat & $\mathrm{btu} / \mathrm{hr}$ & $39,233,873$ & $27,975,457$ & $39,233,873$ & $27,975,457$ \\
\hline Heat Rate & $\mathrm{btu} / \mathrm{kw}-\mathrm{hr}$ & $12,500.00$ & $12,500.00$ & $17,500.00$ & $17,500.00$ \\
\hline Gross Output & $\mathrm{kW}$ & 3,139 & 2,238 & 2,242 & 1,599 \\
\hline Gross Output & $\mathrm{MW}$ & 3.14 & 2.24 & 2.24 & 1.60 \\
\hline Capacity Factor (CF) & $\%$ & $85 \%$ & $85 \%$ & $85 \%$ & $85 \%$ \\
\hline HPY & $\mathrm{hrs}$ & 8,760 & 8,760 & 8,760 & 8,760 \\
\hline CF-hrs & $\mathrm{hrs}$ & 7,446 & 7,446 & 7,446 & 7,446 \\
\hline Net MW-hrs & MWhrs & 19,865 & 14,165 & 14,189 & 10,118 \\
\hline
\end{tabular}

The value for "low efficiency" in Table 7 is based on an assumed plant heat rate of 17,500 Btu/kWh. This is equivalent to a typical mass burn combustion plant today. The value for "high efficiency" assumes a heat rate of $12,500 \mathrm{Btu} / \mathrm{kWh}$. This is equivalent to what some manufacturers of advanced conversion technology gasifers and plasma units are claiming to be able to obtain from their systems.

It should be pointed out that there are no commercial advanced conversion technology WTE projects operating in the United States. Of the WTE systems that are operating in the United States, nearly all (if not all) of the plants use either stoker, fluidized bed, or a similar combustion technology. Combustion technology is fully commercial and lenders are willing to make loans to well-structured projects that have a guaranteed supply of MSW and a power purchase agreement with a credit-worthy customer. Most commercially operated WTE plants are also significantly larger than the size of the plant that could be built in American Samoa.

The numbers in the Table 7 assume that $15 \%$ of the output from the plant will be used for parasitic loads, or electricity usage when an appliance is turned off but still plugged in. In terms of capacity, 
NREL estimates that between 1.6 MW and 3.1 MW of power could be provided from waste on American Samoa. Because WTE can be operated 24/7, a WTE plant produces more energy over a year than an equivalent wind or solar plant. So a 1.6-MW WTE plant would produce approximately the same amount of energy each year as a 4.5-MW wind farm (at 35\% capacity factor), or $7.3 \mathrm{MW}$ of solar at a $22 \%$ capacity factor.

SCS Engineers' Waste Characterization and Waste to Energy Facility Study ${ }^{43}$ reported total capital cost for a WTE project would be $\$ 16$ million (U.S. dollars) for an 82 TPD plant. ${ }^{44}$ Estimated capital costs for the installation of this facility have a wide variability, depending upon the source. The U.S. Virgin Islands awarded a power purchase agreement for the installation of a 16.5-MW (net) WTE facility, which is under development. This facility includes setting up two material recovery facilities (MRFs) for converting MSW to refuse derived fuel (RDF) through a proprietary process called WastAway ${ }^{\mathrm{TM}}$. Material from the two WastAway ${ }^{\mathrm{TM}}$ plants will then be sent to the WTE plant. The developer states that the WastAway process creates a product that is dry and has a Btu content of 7,500 per pound. For comparative purposes, the 16.5-MW (net) WTE plant under development in the U.S. Virgin Islands is estimated to cost $\$ 160$ million ( $\$ 457,000$ per ton/day). The estimated capital cost of a project in American Samoa based on the U.S. Virgin Islands would approach $\$ 32$ million. This is calculated based on assumed capital costs of $\$ 400,000$ per ton per day, which does not include the MRF facility. Other cost comparisons can be performed based on Los Angeles County published data ${ }^{45}$; capital costs for a 25,666 TPD facility would be in the order of \$26 million. With the high variability of installed costs, for this summary NREL is using the LA County report data.

For American Samoa, NREL conducted a preliminary economic analysis of a WTE plant. Results indicate that considering ASPA ownership and a $\$ 0$ net present value to own and operate the plant without collecting a tipping fee, ${ }^{46}$ electricity would need to be sold to ASPA for $\$ 0.23 / \mathrm{kWh}$ to make the project break even over 20 years. For the ASPA to be able to sell power at $\$ 0.19 / \mathrm{kWh}$ (with a 3\% annual escalation), ASPA would need to receive a tipping fee of approximately $\$ 26.04 /$ ton.

It must be pointed out that the numbers above are preliminary and need to be investigated in greater detail. It may be possible for a developer to make the economics work using various technical and economic configurations. The best way to determine what the market can deliver is for ASPA to develop an RFP for WTE and see what bids are received.

\subsection{Technology Assessment}

Technologies commercially available were investigated by SCS Engineers for American Samoa; technologies including combustion and conversion technologies were also with their report. The outcome of their research provided the following conclusions ${ }^{47}$ :

- Mass burn (not applicable)

- $\mathrm{RDF}$ (not applicable)

- Modular starved (applicable)

- Gasification (applicable)

- Plasma arc gasification (not applicable)

- Bio chemical (not applicable)

\footnotetext{
${ }^{43}$ Note: This study was done prior to the tsunami and may need to be refreshed.

${ }^{44}$ Waste Characterization and Waste-to-energy Facility Study, September 17, 2009. Pg 2-3 to 2-4. SCS Engineers.

${ }^{45}$ Ibid

${ }^{46} \mathrm{~A}$ fee collected at a landfill to offset the operation cost.

${ }^{47}$ Ibid.
} 
- Anaerobic digestion (not applicable).

\subsection{Site Economics}

SCS Engineers provided a total cost estimate for the installation of a WTE facility in American Samoa. Their cost estimate is based on private ownership, and approximately an 82 TPD installation. Appendix D: Waste-to-Energy Study Data provides a cost breakdown for their estimate.

American Samoa has three primary contributors to the waste stream, which include the local government, residential, and commercial/industrial entities. Current tipping fees vary depending on the type of customer, and the volume disposed, which is identified in Appendix D: Waste-to-Energy Study Data. The average fee customers are currently paying per ton of waste is $\$ 24.06$.

SCS estimated development and installation of a WTE facility in American Samoa. The project would provide the following debt, which would be covered by a power purchase agreement and electricity sales, along with a tipping fee. The capital costs and debt service is summarized as follows:

- Project ownership, vendor $\$ 15.9$ million - $\$ 4.8$ million treasury

- Annual Debt Service $\$ 1,314,315$

- Power Purchase Agreement \$0.152/kWh

- Tipping fee $\$ 26.04 /$ ton.

\subsubsection{Biodiesel}

Biodiesel is made through the transesterification ${ }^{48}$ of animal fats or vegetable oils. The feedstock can come from wastes sources, such as grease from restaurants, or from virgin sources, such as oil seeds, coconut, palm, jatropha, or algae. In Hawaii, biodiesel is procured from the mainland and Malaysia, though long term plans call for production of feedstocks locally.

The use of biodiesel in utility generators is gaining wider acceptance around the world. The ability of biodiesel to be used within existing utility diesel infrastructure is a compelling reason for exploring this option. There are minimal capital costs associated with using a biodiesel/diesel blend in an existing diesel or residual fuel-oil-fired generators, combustion turbines, or boilers. Biodiesel blends of $2 \%$ up to $20 \%$ can typically be used in existing equipment with only minor modifications. There have been several testing programs aimed at firing $100 \%$ biodiesel in utility-scale boilers, turbines, or generators. Several utilities have been running biodiesel in standby generators as a way to implement peak load reduction and reduce emissions associated with running the generators beyond their annual permitted hours.

The use of $100 \%$ biodiesel in utility-scale generators is being pioneered in Hawaii, where there are at least three different projects underway:

1. Hawaiian Electric Company (HECO) recently completed co-firing tests of various blend percentages of petroleum diesel and biodiesel fuels at the 90-MW Kahe Power Plant. On January 28, 2011, HECO issued a press release stating that they successfully tested $100 \%$ biodiesel in Kahe at the full load of $90 \mathrm{MW}$. Tests will be continuing for the next several months. The next test will demonstrate 24-hour operation on biofuels. One of the major

\footnotetext{
${ }^{48}$ Transesterification is the chemical process of exchanging an organic $\mathrm{R}$ group of an ester with a different organic $\mathrm{R}$ group of an alcohol.
} 
observed results of the tests is that the use of biodiesel reduced opacity, nitrogen oxide, and criteria pollutant emissions below the levels associated with ultra low sulfur diesel fuel. ${ }^{49}$

2. Maui Electric Company (MECO) uses biodiesel to start up and shut down two of its generators. MECO is also conducting tests to determine the long term impact of using biodiesel on heat rates, emissions and engine reliability.

3. HECO's Campbell Industrial Park Generating Station, Combustion Turbine Unit 1, is a brand new (2009) 110-MW combustion turbine unit that is designed to run on $100 \%$ biodiesel. Renewable Energy Group of Iowa presently has a contract to supply three to seven million gallons of biodiesel per year. All biofuel procured by HECO must meet stringent sustainability guidelines. HECO has determined that the use of biodiesel is its most costeffective option for complying with Hawaii's renewable energy targets.

The major issue to evaluate as to whether biodiesel makes sense for American Samoa is supply and cost. The amount of waste grease produced in American Samoa is not known. There is no known inventory of fats, oils, and greases for American Samoa and there is limited agricultural land available for production of commercial quantities of oil. It is recommended that American Samoa begin an inventory of fats, oils, and greases to better estimate the cost of potentially producing Biofuels. Biofuels could be produced from fish oil, and fish oil could also be fired directly in the existing generators.

\subsubsection{Anaerobic Digestion}

Fishery processing facilities are a vital contributor to American Samoa's economy. A portion of the canneries' waste stream is biogenic waste, which is an ideal feedstock for anaerobic digestion. Additionally, anaerobic digestion can be incorporated into the wastewater treatment infrastructure. Anaerobic digestion escalates the natural breakdown of biogenic/organic materials in a minimum oxygen environment to generate a biogas. The biogas primarily consists of methane and carbon dioxide. Typically, anaerobic digestion can generate a 500 to $700 \mathrm{Btu} / \mathrm{ft}^{3}$ biogas, which can be used in boilers to generate hot water or steam for process, or be directly combusted in an internal combustion engine to generate electricity. Further analysis of the waste stream and the wastewater treatment plant should be performed, to determine the applicability of anaerobic digestion directly on-site at the facilities.

\subsubsection{Small-scale Biomass}

There may be niche opportunities within the agricultural sector for small-scale biomass or biogas utilization. This opportunity is lower priority in terms of generation potential. American Samoa Community College Agricultural Departments and United States Department Agriculture/National Resource Conservation Service are best situated to lead future efforts in this area.

\subsubsection{Production of Dedicated Biomass Feedstocks}

The production of dedicated biomass feedstocks for biofuels or for use in a solid fuel plant has not been investigated in detail. Many island communities are investigating this option. For example, there are several companies and groups in Hawaii that are developing plans for locally grown biofuels production.

However, based on the initial site visit, NREL believes that growing bioenergy feedstocks on American Samoa will present the following challenges:

- Small land area with steep hills, rocky cliffs, and densely growing jungle

- There is not a large agricultural industry in American Samoa, and there are very few commercial operations

\footnotetext{
${ }^{49}$ HECO Press Release. Available online at: www.heco.com/portal/site/heco/menuitem.508576f78baa14340b4c0610c510b1 ca/?vgnextoid=9fbfb7ba04ecd210VgnVCM1 000005c011bacRCRD\&vgnextfmt=default\&cpsextcurrchannel=1. Accessed 1/31/2011.
} 
- There are a large number of small-scale farmers with acreages from 1 to 50 acres.

\subsubsection{Biomass Next Steps}

Biomass utilization and WTE should make up some component of a wider energy strategy for American Samoa. Biomass offers many strategic benefits, such as biofuels can fit into the existing oil based infrastructure nearly seamlessly. Other resources, such as WTE, anaerobic digestion of biogenic materials from local canneries, and methane from waste water treatment plants, can be used to produce baseload power and are not subject to intermittent outages as are wind and solar.

One of the next steps would be to conduct a comprehensive biomass resource assessment and analysis of opportunities. The assessment could be performed all at one time by a single entity, or the work could be split among a team of researchers. Several activities would lend themselves to being performed by students and staff from the University of American Samoa.

\subsection{Waste-to-Energy}

WTE is a small but important part of any strategic effort to develop renewable resources on American Samoa. The following next steps are suggested. With the detailed waste sort and flow analysis, an RFP should be issued to substantiate true capital costs for American Samoa.

1. Evaluate local recycling efforts, markets and options and determine potential impacts on the waste stream and the economics of WTE.

2. ASPA should weigh the options between owning a WTE facility, versus offering a power purchase agreement to a private entity. There currently is a $30 \%$ capital cost difference between owning and purchasing the power.

\subsection{Biodiesel Assessment}

The production of or use of biodiesel warrants further investigation. Recommended steps include:

- Conduct a survey of waste grease supplies on American Samoa. Determine who produces the material, how it is collected and disposed, what the costs are, and whether there are any opportunities for a local business to manufacture biodiesel locally.

- Determine the expected costs of procuring biodiesel from the mainland or Asia.

- Gather case study data associated with the use of biofuels in diesel systems in Hawaii, other islands, or other communities.

- Determine equipment modifications needed to use biodiesel in the ASPA system. Based on other case studies or work done in Hawaii, it would be useful for ASPA to conduct a test of biofuel use within its system. This would be a comprehensive assessment that evaluates costs, impacts on heat rates and performance, fuel storage and handling, air emissions and overall feasibility.

- Estimate the levelized cost of energy of energy produced from biodiesel in various blends of biodiesel/petroleum diesel percentages.

- Prepare a report and briefing for ASPA and the Energy Steering Committee to communicate results of the detailed assessment.

\subsection{Anaerobic Digestion}

Recommended steps include:

- Work with the local commercial cannery to validate their plan to lower operation costs. Identify their waste stream of biogenic materials, and their fuel requirements for current 
operations. Evaluate the economic and technical feasibility of adding anaerobic digestion to their wastewater and fish waste stream.

- Possibly develop a plan for a cooperative with the commercial cannery to evaluate the economic and technical feasibility of combining all the fish waste streams and develop a common anaerobic digestion system for power generation. 


\section{Workforce Development}

The development of a trained workforce to develop and expand new energy industries will be critical for American Samoa to increase the use of energy-efficient and renewable energy technologies.

Additionally, the local development of these industries as compared to their importation from other locations will also allow more economic development for residents. ASPA has almost 12,000 unique customers, which provides an indication of the number of potential customers that could benefit from additional energy services in the form of energy audits, energy efficient retrofits, or distributed renewable energy systems.

Although renewable energy components are not likely to be manufactured in American Samoa, the installation of all renewable energy technologies is generally labor intensive and could provide a good amount of jobs if the communities are able to take advantage of these opportunities.

American Samoa has the groundwork in place to develop a strong, local renewables and efficiency implementation industry. The implementation of renewable technologies at various sites and the planned installation of the utility-scale PV project at the airport can serve as the foundational support, knowledge base, and demonstrational viability of these technologies. Incorporation of renewable energy technology and applications into the K-12 and vocational/community college curricula can serve as both an outreach and educational component that will support economic development.

American Samoa already has several renewable energy focused private companies as well as interested citizens, both of which will play a key role in developing an active industry on the islands. Any strides in this area will require the training and retraining of individuals in green building techniques-home energy auditing, energy efficiency retrofits, or new construction — and renewable energy installation and maintenance. Many of these skills can be applied through traditional vocational training programs combined with apprentice programs, while others must be conducted by accredited programs that provide associate and other certificate degrees.

\subsection{Workforce Development Next Steps}

1. The Renewable Energy Committee Education subcommittee should determine opportunities, resources, and curricula available to offer increase energy education within the existing K-12 courses

2. Determine needs, opportunities, resources, and curricula available to incorporate energy efficiency and renewable energy training into vocational classes at the community college.

3. Connect with the Weatherization Program in the Weatherization and Intergovernmental Program (WIP) at DOE to determine what if any opportunities there are for assistance. 


\section{Policy Development}

The existing policies should be reviewed and evaluated for effectiveness; effective policies should remain and be promoted while ineffective policies should be evaluated for potential improvement and amended or eliminated. Creating an effective policy environment is important for the deployment of energy efficiency and renewable energy technologies. Below is a framework outline that could be used in determining needs and developing a policy framework:

- How is the energy discussion being framed?

- What high-level support is there (federal, territorial, local)?

- Identify the support; finances, technical assistance, education, and outreach activities

- How does clean energy address island core values? Find and identify all the connections.

○ Is there energy literacy in the community, business sector, and local trades?

- What are the energy goals (federal, territorial, local), or what goals can be developed?

○ This should cover all sectors; water, agriculture, aquaculture, recreation, tourism

- Identifying all barriers

- Social awareness and acceptance

○ Financial

- Technical

○ Workforce

- Education.

- Surveying current policy_What are the existing energy-related policies?

- Are they effective? How can they be more effective?

- What policy changes are needed?

- Is there a local/village connection?

- Policy analysis

- What technologies support American Samoa's goals, objectives, and budget?

- What are the policies and programs to support those technologies?

- What existing policies support or hinder American Samoa's energy goals?

- Implementation and action plan

- Implementation strategies

○ Budgets and timelines

- Measurement and verification

○ Re-assessment.

Addressing these topics through consideration of current policies and determining opportunities to develop new policies and programs sets a sturdy foundation for achieving energy goals. 


\subsection{Policy Next Steps}

Developing a policy environment that allows for and supports energy efficiency and renewable energy technologies is a key component of achieving American Samoa's clean energy goals. Potential policy options include the following:

1. Renewable Portfolio Standard (RPS): An RPS mandates, through legislation, that the utility achieve a specified amount of electricity generation from renewable energy sources by a set year. These policies typically identify the type of renewable energy sources that count toward the RPS and may include incremental targets for interim years. See the Database of State Incentives for Renewables and Efficiency for examples of current state RPS (www.dsireusa.org).

2. Energy Efficiency Resource Standard (EERS): Similar to an RPS, an EERS mandates through legislation that total projected electricity use is reduced by a certain percentage by a set year. This type of policy incentivizes the utility to invest in energy efficiency improvements in both operations and end-use. See the Database of State Incentives for Renewables and Efficiency for examples of current state RPSs (www.dsireusa.org).

3. Energy Efficiency Building Codes: The adoption and enforcement of energy-efficient building codes in both the residential and commercial sectors ensures that all new construction will be built to a minimum efficiency standard. The current standard for the most energy efficient residential codes is 2009 IECC and for commercial codes is American Society of Heating, Refrigerating, and Air Conditioning Engineers 90.1-2007 or the equivalent. $^{50}$

4. Assess Utility Rate Cross-subsidization: Cross-subsidization is a regular practice around the world and often used to provide equitable access to utility services. However, crosssubsidization of utility rates based on location or type of utility service (e.g. using revenues generated from electricity sales to support other utility services) results in an economically inefficient use of those utility services. In the case of electricity rate cross-subsidization, this practice may impede the development of energy efficiency and renewable energy projects where it would otherwise currently be cost-effective to development clean energy projects.

5. "Lead-by-Example" Policies: A government can lead by example by setting energy efficiency standards and goals for public buildings and operations that are above and beyond those established for the rest of the community. These types of policies not only save costs associated with energy use in the public sector, but also demonstrate to the broader community the effectiveness of energy efficiency technologies. These types of policies can be mandated through legislation or developed through an executive order.

6. Incentivize Energy Savings in Territorial Government Agencies: Government agencies do not have an incentive to use electricity efficiently because they do not currently pay for their electricity out of their operations budget as the bills are paid directly by the territorial government to ASPA. If the funds used for electricity bills were included in the annual operations budget for each agency, they would better understand the costs associated with their energy use. Allowing the agency to retain some or all of the funding allotted for electricity use if it is not used during the year, would create an incentive for each agency to use electricity in an efficient manner.

\footnotetext{
${ }^{50}$ Building Codes Assistance Project. 2011. http://bcap-energy.org.
} 


\section{Summary of Recommendations and Conclusions}

The site visit and subsequent research on American Samoa's energy efficiency and renewable energy opportunities is a basic, preliminary overview to provide the Energy Task Force with a set of next steps. The areas of opportunity that have been identified are based on this preliminary review. Further investigation or consultation may be required before undertaking any next steps. The key opportunities, potential steps for policy, and concluding points are summarized in this section.

\subsection{Key Opportunities}

\section{General}

- Develop an outreach strategy: The current lack of information on energy efficiency and renewable energy opportunities impedes adoption of clean energy technologies. Providing unbiased information to the public on the costs and benefits of these technologies could address the information barrier to adoption and potentially provide residents with strategies to reduce their electricity use and associated costs.

- Based on existing overall baseline energy use, set priorities and develop specific goals to reduce overall fossil fuel consumption. Energy efficiency and conservation efforts should be at the forefront of this discussion.

- Develop a strategic energy plan. The plan should include an implementation strategy to implement near-term opportunities identified in this report, and approaches for further feasibility analysis to identify and implement longer-term opportunities.

- Policies, programs, and regulations should be reviewed for energy efficiency and renewable energy targets.

- Conduct a transportation assessment to determine fuel usage, analyze options, and identify fuel reduction and/or renewable strategies.

\section{Energy Efficiency}

- Conduct and energy end-use study.

- Provide educational materials to address specific information and outreach needs. Flyers, posters, and stickers can be designed and distributed among the appropriate building sectors.

- Provide training courses and materials for both architects and workers in the construction sector to improve energy awareness. Energy efficiency in retrofit, renovation, and new construction can be integrated into the construction process terms of planning, design, materials, and equipment.

- Create guidebooks and self-assessment checklists. These guidebooks could be designed as stand-alone products for specific sectors or integrated into the training courses described above.

- Evaluate and consider alternative cooling technologies such as green roofs and solar airconditioning.

- Determine if a cool roof program is appropriate and feasible.

- Utilize the existing ARRA building audits and subsequent energy conservation measures to build a building portfolio; measure performance as retrofits occur, compare savings and evaluate lessons learned.

- Perform water audits and utilize the results to benefit the entire building portfolio. 
- Develop residential audit programs or incentives to encourage energy conservation and efficiency in homes.

\section{Renewable Energy}

- Conduct a renewable energy grid integration study.

- Complete wind anemometry studies and analyze results to determine wind energy potential.

- All renewable assessments should be followed by a detailed feasibility and economic assessment of the best project sites, including an interconnection study.

- Identify available land area for renewable energy development. This should consider zoning, avian, and other environmental considerations.

- Develop solar water heating implementation programs for residential, commercial, and government buildings.

- Consideration of WTE potential and resource assessments as described in this report should be conducted.

\subsection{Conclusion}

There are many opportunities to be found in American Samoa for the adoption of energy efficiency and renewable energy technologies as well as implementation of energy policies, standards, and codes that have been outlined.

As a result of the economic impacts of fluctuating energy prices, including the record high price for oil in 2008, American Samoa recognizes the immediate need to address energy consumption and costs. American Samoa is in a unique position to undertake a concerted effort to address current energy and environmental challenges. Due to its geographic isolation, non-renewable resources are extremely limited and subject to large volatility in pricing and availability. Energy security is fundamental to the long-term economic future and sustainability of American Samoa. Consequently, creating a stable investment atmosphere remains challenging, while the quality of life for residents and visitors continues to be affected. However, the unique position of American Samoa also offers many natural advantages, as the territory is endowed with diverse sources of alternative energy.

A strong energy plan begins by surveying the current situation and assessing both current and future needs. It provides analysis and recommendations for appropriate technologies, policies, and programs relevant to its environment while addressing economic viability. It addresses a full range of energy options, with a focus on energy efficiency and renewable energy technologies, prioritizes opportunities, and maps out a road in which a community may follow in order to reach long-term energy security and socioeconomic development. The roadmap includes implementation strategies for action that will ensure energy efficiency and renewable energy programs and projects achieve local market adoption and deployment. This will serve as the starting point and pathway to greater energy security and economic sustainability. 


\section{Appendix A: Generation Capacity Tables}

The information contained in this appendix includes the pre-tsunami and post-tsunami generation capacities.

Table 8. Pre-tsunami Generation Capacity (Before September 29, 2009) ${ }^{51}$

Tafuna Power Plant

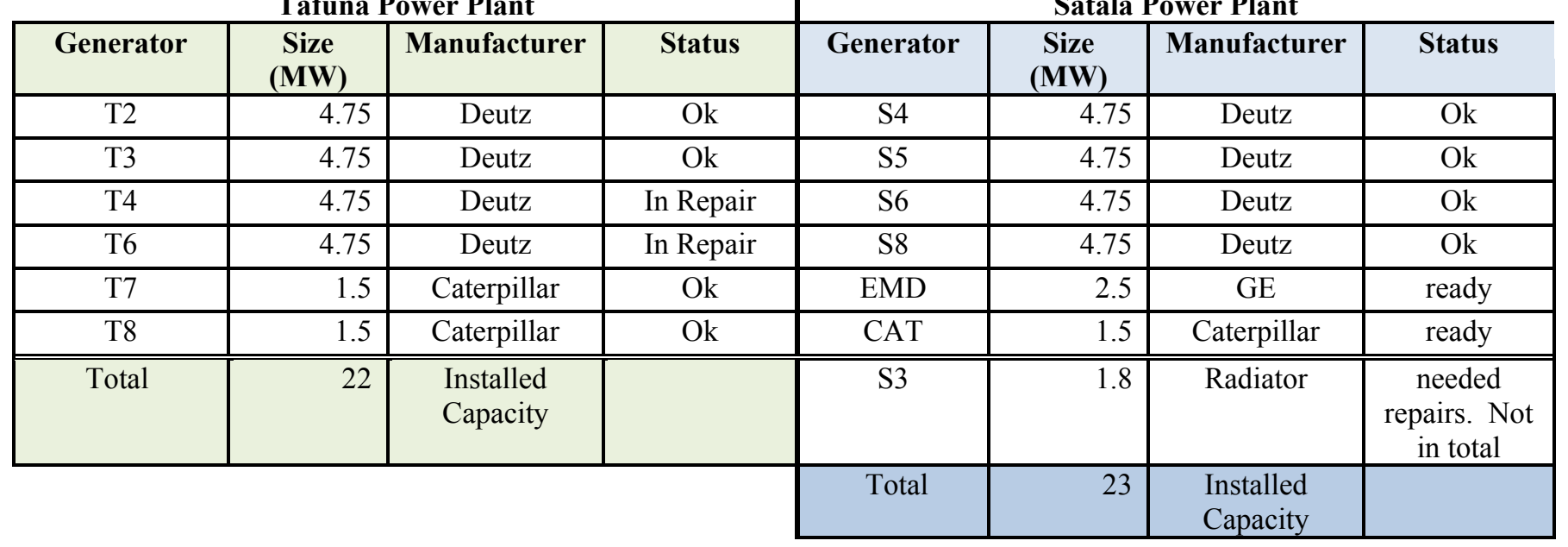

Table 9. Post-tsunami Generation Capacity, Tier II (Since Approximately December 2009) ${ }^{52}$

\begin{tabular}{|c|c|c|c|c|c|c|c|}
\hline \multicolumn{4}{|c|}{ Tafuna Power Plant } & \multicolumn{4}{|c|}{ Satala Power Plant } \\
\hline Generator & $\begin{array}{c}\text { Size } \\
(\mathrm{MW})\end{array}$ & Manufacturer & Status & Generator & $\begin{array}{c}\text { Size } \\
\text { (MW) }\end{array}$ & Manufacturer & Status \\
\hline $\mathrm{T} 2$ & 4.75 & Deutz & Ok & $18 \times 1 \mathrm{MW}$ & 18 & Aggreko & temporary \\
\hline $\mathrm{T} 3$ & 4.75 & Deutz & Ok & & 18 & $\begin{array}{l}\text { Installed } \\
\text { Capacity }\end{array}$ & \\
\hline $\mathrm{T} 4$ & 4.75 & Deutz & In Repair & & & & \\
\hline $\mathrm{T} 7$ & 1.5 & Caterpillar & Ok & & & & \\
\hline $\mathrm{T} 8$ & 1.5 & Caterpillar & Ok & & & & \\
\hline \multirow[t]{2}{*}{$9 \times 1 \mathrm{MW}$} & 9 & Aggreko & temporary & & & & \\
\hline & 31 & $\begin{array}{l}\text { Installed } \\
\text { Capacity }\end{array}$ & & & & & \\
\hline
\end{tabular}

${ }^{51}$ ASPA Energy and Financial Security presentation, November 2010.

${ }^{52}$ Ibid. 


\section{Appendix B: Waste Sort Data}

This appendix includes information from the Waste Characterization and Waste to Energy Facility Study.

Table 10. Annual Averages Based on Three-Week Data ${ }^{53}$

\begin{tabular}{|c|c|c|c|c|}
\hline $\begin{array}{l}\text { Account/Name, } \\
\text { Truck Type }\end{array}$ & Sector & $\begin{array}{l}\text { Net Weight } \\
\text { (T/yr) }\end{array}$ & $\%$ of Sector & $\%$ of Total \\
\hline $\begin{array}{l}\text { ASG/ASPA } \\
\text { Pickup Truck }\end{array}$ & ASG \& Res & 318 & $5.5 \%$ & $5.5 \%$ \\
\hline $\begin{array}{l}\text { ASCC Pickup } \\
\text { Truck }\end{array}$ & ASG \& Res & 17 & $0.3 \%$ & $0.3 \%$ \\
\hline $\begin{array}{l}\text { ASPA Bucket } \\
\text { Truck }\end{array}$ & ASG \& Res & 12 & $0.2 \%$ & $0.2 \%$ \\
\hline $\begin{array}{l}\text { ASPA Flat Bed } \\
\text { Truck }\end{array}$ & ASG \& Res & 2,136 & $36.7 \%$ & $36.7 \%$ \\
\hline $\begin{array}{l}\text { ASPA Side } \\
\text { Loader }\end{array}$ & ASG \& Res & 2,829 & $48.6 \%$ & $48.6 \%$ \\
\hline Family Trash & ASG \& Res & 473 & $8.1 \%$ & $8.1 \%$ \\
\hline $\begin{array}{l}\text { Total, ASG \& } \\
\text { Residential }\end{array}$ & & 5,785 & & $27.7 \%$ \\
\hline $\begin{array}{l}\text { Starkist (Reg. } \\
\text { Trash) }\end{array}$ & Commercial & 1,457 & $9.6 \%$ & $9.6 \%$ \\
\hline $\begin{array}{l}\text { Starkist (Waste } \\
\text { Fish) }\end{array}$ & Commercial & 929 & $6.1 \%$ & $6.1 \%$ \\
\hline $\begin{array}{l}\text { Commercial } \\
\text { Front End } \\
\text { Loader } \\
\end{array}$ & Commercial & 11,832 & $78 \%$ & $78 \%$ \\
\hline $\begin{array}{l}\text { Mixed } \\
\text { Commercial }\end{array}$ & Commercial & 957 & $6.3 \%$ & $6.3 \%$ \\
\hline Total For Year & & 20,960 & & \\
\hline
\end{tabular}

Table 11. Most Prevalent Materials Identified by Waste Sort

\begin{tabular}{|l|r|r|r|}
\hline Material Type & Tons & Mean \% & Cum \% \\
\hline Cardboard and Kraft & 4003 & $19.1 \%$ & $19.1 \%$ \\
\hline Ferrous Cans & 3364 & $16.0 \%$ & $35.1 \%$ \\
\hline Misc. Residue & 2390 & $11.4 \%$ & $46.6 \%$ \\
\hline Yard Waste & 1076 & $5.1 \%$ & $51.7 \%$ \\
\hline Diapers & 1061 & $5.1 \%$ & $56.7 \%$ \\
\hline Fish Meal & 919 & $4.4 \%$ & $61.1 \%$ \\
\hline Food Waste & 875 & $4.2 \%$ & $65.3 \%$ \\
\hline Fish Waste & 826 & $3.9 \%$ & $69.2 \%$ \\
\hline Bag Film Plastic & 792 & $3.8 \%$ & $73.0 \%$ \\
\hline Boxboard & 543 & $2.6 \%$ & $75.6 \%$ \\
\hline Total & $\mathbf{1 5 8 4 9}$ & & $\mathbf{7 5 . 6 \%}$ \\
\hline
\end{tabular}

${ }^{53}$ Waste Characterization and Waste to Energy Facility Study, September 17, 2009. Pg 2-3 to 2-4. SCS Engineers. 
Table 12. Heat Rate Analysis for American Samoa

\begin{tabular}{|c|c|c|c|c|c|}
\hline Waste Type & \begin{tabular}{|l|} 
Portion of \\
Overall \\
Waste \\
stream \\
\end{tabular} & $\begin{array}{l}\text { Inherent } \\
\text { Energy } \\
\text { (Btu/lb) }\end{array}$ & $\begin{array}{l}\text { Moisture } \\
\text { Content }\end{array}$ & $\begin{array}{l}\text { Revised } \\
\text { Energy } \\
\text { (Btu/lb) }\end{array}$ & $\begin{array}{l}\text { Total } \\
\text { Energy } \\
\text { Contribution } \\
\text { (Btu/lb) } \\
\end{array}$ \\
\hline Food waste & $3.5 \%$ & 2,000 & $92.5 \%$ & 151 & 5 \\
\hline Paper & $6.7 \%$ & 7,200 & $23.5 \%$ & 5,508 & 371 \\
\hline Cardboard & $17.6 \%$ & 7,000 & $52.5 \%$ & 3,325 & 586 \\
\hline Plastics & $11.8 \%$ & 14,000 & $23.0 \%$ & 10,780 & 1,272 \\
\hline Textiles & $3.9 \%$ & 7,500 & $23.5 \%$ & 5,738 & 221 \\
\hline Rubber & 0 & 10,000 & & 10,000 & 5 \\
\hline Leather & $0.0 \%$ & 7,500 & & 7,500 & \\
\hline $\begin{array}{l}\text { Garden } \\
\text { trimmings }\end{array}$ & $10.6 \%$ & 2,800 & $66.5 \%$ & 938 & 99 \\
\hline Wood & \begin{tabular}{|l|}
$1.2 \%$ \\
\end{tabular} & 8,000 & & 8,000 & 93 \\
\hline Glass & $3.2 \%$ & 60 & & 60 & 2 \\
\hline Tin Cans & $4.7 \%$ & 300 & & 300 & 14 \\
\hline $\begin{array}{l}\text { Non ferrous } \\
\text { metals }\end{array}$ & $1.3 \%$ & $\mathbf{0}$ & & $\overline{0}$ & $\mathbf{0}$ \\
\hline $\begin{array}{l}\text { Ferrous } \\
\text { metals }\end{array}$ & $0.5 \%$ & 300 & & 300 & 1 \\
\hline $\begin{array}{l}\text { Dirt, ashes, } \\
\text { brick, etc }\end{array}$ & $0.0 \%$ & 3,000 & & 3,000 & 1 \\
\hline $\begin{array}{l}\text { Municipal } \\
\text { solid wastes } \\
\text { (Mixed } \\
\text { Residues) }\end{array}$ & \begin{tabular}{|l|}
$15.0 \%$ \\
\end{tabular} & 4,500 & $70 \%$ & 1,350 & 202 \\
\hline Waste Oil & $2.2 \%$ & $21,{ }^{54} 000$ & $92.5 \%$ & 21,000 & 472 \\
\hline Tires & $5.3 \%$ & 13,500 & $23.5 \%$ & 13,500 & 713 \\
\hline Total & $87.4 \%$ & & & & 4,058 \\
\hline
\end{tabular}

${ }^{54}$ Waste Characterization and Waste to Energy Facility Study, September 17, 2009. Pg 5-14. SCS Engineers. 


\section{Appendix C: Solar Radiation Data}

This appendix contains information from the Atmospheric Science Data Center NASA Surface meteorology and Solar Energy: RETScreen Data.

Table 13. Solar Resource in American Samoa ${ }^{55}$

\begin{tabular}{|l|c|}
\hline \multicolumn{1}{|c|}{ Month } & $\begin{array}{c}\text { Daily solar } \\
\text { radiation - } \\
\text { horizontal }\end{array}$ \\
\hline $\mathrm{kWh} / \mathrm{m}^{2} / \mathrm{d}$ \\
\hline January & 5.71 \\
\hline February & 5.75 \\
\hline March & 5.55 \\
\hline April & 5.22 \\
\hline May & 4.65 \\
\hline June & 4.45 \\
\hline July & 4.67 \\
\hline August & 5.33 \\
\hline September & 5.88 \\
\hline October & 6.04 \\
\hline November & 6 \\
\hline December & 5.84 \\
\hline $\begin{array}{l}\text { Annual } \\
\text { Average }\end{array}$ & 5.42 \\
\hline
\end{tabular}

${ }^{55} \mathrm{http} / / /$ eosweb.larc.nasa.gov/cgi-bin/sse/retscreen.cgi?email=rets@nrcan.gc.ca\&step=1\&lat=-14.33046+\&lon=170\&submit=Submit. 


\section{Appendix D: Waste-to-Energy Study Data}

This appendix contains information related to the WTE study conducted by SCS Engineers.

Table 14. Capital Cost for 82 TPD WTE

\begin{tabular}{|l|l|}
\hline Facility Cost Item & Costs \\
\hline Land & $\mathbf{0}$ \\
\hline Building @\$200/sq. foot & $\mathbf{2 , 0 0 0 , 0 0 0}$ \\
\hline $\begin{array}{l}\text { Combustion, Ash Handling, and Air } \\
\text { Emission Control Equipment }\end{array}$ & $\mathbf{7 , 0 0 0 , 0 0 0}$ \\
\hline $\begin{array}{l}\text { Waste Heat Recovery and Power } \\
\text { Generation Equip with SCADA/Data } \\
\text { Recording/Control Systems }\end{array}$ & $\mathbf{3 , 2 0 0 , 0 0 0}$ \\
\hline Scale House/Weighing System & $\mathbf{2 0 0 , 0 0 0}$ \\
\hline Utilities and Substation/Tie In & $\mathbf{2 0 0 , 0 0 0}$ \\
\hline Rolling Stock & $\mathbf{2 0 0 , 0 0 0}$ \\
\hline Engineering, Installation, Testing & $\mathbf{4 0 0 , 0 0 0}$ \\
\hline Permitting and Implementation & $\mathbf{3 0 0 , 0 0 0}$ \\
\hline Freight & $\mathbf{4 0 0 , 0 0 0}$ \\
\hline \multicolumn{1}{|c|}{ Total Capital Costs } & $\mathbf{1 3 , 9 0 0 , 0 0 0}$ \\
\hline Contingency (15\%) & $\mathbf{\$ 1 5 , 9 8 5 , 0 0 0}$ \\
\hline $\begin{array}{l}\text { Treasury Grant (30\% of Total Capital } \\
\text { Costs) }\end{array}$ & $\mathbf{4 , 7 8 5 , 5 0 0}$ \\
\hline Total Capital Costs - Minus Treasury & $\mathbf{\$ 1 1 , 1 8 9 , 5 0 0}$ \\
\hline
\end{tabular}

Table 15. Landfill Tipping Fee

\begin{tabular}{|c|c|c|c|c|}
\hline Customer Classification & $\begin{array}{l}\text { Number of } \\
\text { Customers }\end{array}$ & $\begin{array}{l}\text { Current } \\
\text { \$/account }\end{array}$ & $\begin{array}{l}\text { Previous } \\
\text { \$/account/mo }\end{array}$ & $\begin{array}{l}\text { Expected } \\
10 / 2012\end{array}$ \\
\hline Residential & 10,139 & $\$ 3.00$ & $\$ 1.00$ & $\$ 10.36$ \\
\hline $\begin{array}{l}\text { American Samoa } \\
\text { Government }\end{array}$ & 511 & & & \\
\hline Commercial & 872 & $\$ 280$ & & $\$ 115$ \\
\hline $\begin{array}{l}\text { Industrial } \\
- \text { Up to } 10 \mathrm{cy} \\
-11 \text { to } 20 \mathrm{cy} \\
- \text { Over } 20 \mathrm{cy} \\
\text {-Canneries }\end{array}$ & 6 & $\begin{array}{l}\$ 72 \\
\$ 102 \\
\$ 135 \\
\$ 162\end{array}$ & & \\
\hline
\end{tabular}

